\title{
17. -20. Yüzyıl Arası Resim Sanatı Örneklerinde İstanbul Tasvirleri Ve Kentsel Bellek
}

\author{
Deniz DEMIRARSLAN ${ }^{1}$ \\ Emine Begüm SAVCIN²*
}

Öz

Tüm gelişmiş canlılar gibi kentlerin de bir belleği bulunmaktadır. Kentin belleği aynı zamanda toplumun belleğidir. Kentler (kentliler) geçmişten bugüne, yaşanan tüm gelişmeleri belleğinde tutarken; bu birikim de farklı biçimlerde kent mekânına ve kent yaşantısına yansımaktadır. Kentte zaman içindeki toplumsal ve mekânsal değişimin, yaşayanlar üzerinde bıraktığı toplu izlenimler o kentin belleğini oluşturmaktadır. Kentin belleği ya da toplumsal bellek, mekân/yer-zaman-anı-kimlik birlikteliğinden oluşmaktadır. Kentsel belleğin oluşturulmasında anıtlar, tarihi yapılar, müzeler, kamusal alanda yer alan sanat eserleri, fotoğraf, film, resim, gravür vb. görsel kültür öğeleri olan sanatsal ve mimari çalışmaların yeri ve önemi büyüktür. Söz konusu İstanbul şehri olunca özellikle tarihi ve mimari özellikleri açısından İstanbul'un gelişimini izleyebileceğimiz ve görsel kültürel belleğin oluşumunu sağlayan araçlar arasında resim sanatına ilişkin yağlı boya tablo, sulu boya resim ve gravür çalışmaları önemli bir yer tutmaktadır. Bu çalışmada İstanbul'u konu alan 17., 18., $19 ., 20$. yüzyıl Batılı ve Türk ressamların resimleri arasından Eminönü, Tophane, Üsküdar semtlerini konu alan resimler seçilmiş, bu resimlerin konu edindiği mekanlar incelenmiş, aynı mekanların aynı dönemdeki fotoğraf çalışmaları ile ve günümüzdeki durumu ile karşılaştırmaları yapılmıştır. Birbirinden farklı kültür yapısına sahip olan sanatçıların ürettikleri bu sanat eserlerinde İstanbul'a yaklaşımlarını, yorumlarını hatta şehrin ruhunu izleyiciye hissettirme biçimiyle birlikte, bu resim örneklerinin kentsel bellek konusunda bizleri nasıl yönlendirdiği ve yönlendireceği belirlenmiş bulunmaktadır.

Anahtar Kelimeler: Kentsel bellek, Istanbul, Resim Sanatı, Oryantalizm, Türk Resim Sanatı.

\section{Urban Memory and a Study on Istanbul Description Painting Art Examples Between 17th and 20th Centuries}

\begin{abstract}
Like all sophisticated creatures, cities also have a memory. The memory of the city is also a memory of the society at the same time. While the cities (urbanites) keep in mind the past to present, all the developments that are happening; this accumulation is also reflected in different forms of urban space and urban life. Collective impressions of the city and its spatial and temporal change over time make up the memory of that city. The memory of the city or the social memory consists of the combination of space / place-time-momentidentity. In the creation of urban memory, monuments, historical buildings, museums, works of art in public places, photographs, films, paintings, engravings and so on. The place of artistic and architectural works, which are visual cultural elements and the importance, is great. Especially when it comes to the city of Istanbul, oil paintings, watercolour paintings and engraving works are important for the formation of visual cultural memories that we can observe the development of Istanbul especially in terms of its historical and architectural characteristics. In this study, paintings about Eminönü, Tophane and Üsküdar districts were selected from the paintings of 17th, 18th, 19th and 20th century Western and Turkish painters who were about Istanbul and the places where these paintings were subject were examined and the same places were photographed and compared with the current situation. and it has been determined how these picture examples will guide and guide us about urban memory. Finally, It has been determined how these examples of paintings orient and direct us about urban memory, along with the manner in which the artists who have different cultural structures produce their approaches to Istanbul, their interpretations, and even the audience's feelings in the spirit of the city.
\end{abstract}

Keywords: Urban Memory, Istanbul, Painting Art, Orientalizm, Turkish Painting Art.

\footnotetext{
${ }^{1}$ Doç. Dr., Kocaeli Üniversitesi, Mimarlık ve Tasarım Fakültesi, İç Mimarlık Bölümü, denizdemirarslan@gmail.com

${ }^{2}$ Arş. Gör., Kocaeli Üniversitesi, Mimarlık ve Tasarım Fakültesi, İç Mimarlık Bölümü, begumsavcin@gmail.com *ilgili yazar / Corresponding author: Emine Begüm SAVCIN, begumsavcin@gmail.com
}

Gönderim tarihi: 14.04.2017

Kabul tarihi: 20.04.2017 


\section{GíRiş}

Yaşananları, öğrenilen konuları, bunların geçmişle ilişkisini bilinçli bir şekilde zihinde saklama gücü olarak tanımlanan bellek, yaşadığımız şehirlerin değişimi ve gelişimi açısından önemli bir konudur. Tüm gelişmiş canlılar gibi kentlerin de bir belleği bulunmaktadır. Bu bellekten yararlanma düzeyi kentlerin gelişim biçimini derinden etkiler. Kentlerin beyni, yani kenti çekip çeviren, ona yön veren çevreler ve karar vericiler zaman zaman kentin belleğine müdahale ederler (URL-1). Kentler yaşayan birer organizma olarak, toplumlara benzer ve onları aşan tarihleriyle barındırdıkları tüm sosyal gruplara, sınıfsal yapılara kendilerinden bir şeyler katarlar. Kentin belleği aynı zamanda toplumun belleğidir. Kentler ve kentliler geçmişten bugüne, yaşanan tüm gelişmeleri belleğinde tutarken; bu birikim de farklı biçimlerde kent mekânına ve kent yaşantısına yansımaktadır. Kentte zaman içindeki toplumsal ve mekânsal değişimin, yaşayanlar üzerinde bıraktığı toplu izlenimler o kentin belleğini oluşturmaktadır. Kentin belleği ya da toplumsal bellek, mekân/yer-zaman-anı-kimlik birlikteliğinden oluşmaktadır (URL-2).

Dünyada her iki kıtaya yayılan ve tarihsel süreçte çok eski dönemlere dayanan geçmişiyle Ceneviz, Bizans, Osmanlı gibi çok zengin uygarlıklara ev sahipliği yapan İstanbul kentsel bellek açısından önemli bir şehirdir. Özellikle 20. yüzyılda ve günümüzde kentsel dönüşüm, ulaşım, kentsel düzenleme çalışmaları ile çok büyük ve önemli değişimler yaşayan İstanbul şehrinin genel görünümünün değişikliğe uğradığı açıkça görülmektedir. Kentsel belleğin oluşturulmasında anıtlar, tarihi yapılar, müzeler, kamusal alanda yer alan sanat eserleri, fotoğraf, film, resim, gravür tekniği vb. görsel kültür öğeleri olan sanatsal ve mimari çalışmaların yeri ve önemi büyüktür. Söz konusu İstanbul şehri olunca özellikle tarihi ve mimari özellikleri açısından İstanbul'un gelişimini izleyebileceğimiz ve görsel kültürel belleğin oluşumunu sağlayan araçlar arasında resim sanatına ilişkin yağlı boya tablo, sulu boya resim ve gravür tekniğinde yapılmış çalışmalar önemli bir yer tutmaktadır. Özellikle 17. yüzyılın sonlarından başlayarak ve 19. yüzyılda Osmanlı Devleti'ni ziyaret eden Oryantalist gezgin ve ressamların İstanbul'u betimleyen çalışmaları bizlere bu konuda önemli görsel kaynakları oluşturmaktadır. Örneğin Melling'in yapmış olduğu gravürlerden yola çıkılarak Tophane Çeşmesi'nin çatısı 1950'li yıllarda aslına uygun olarak yeniden restore edilebilmiştir (URL-3). Ayrıca, yine 17. Yüzyılda Fransız ressam ve gezgin Guillaume- Joseph Grelot'un "İstanbul Seyahatnamesi” isimli eserinde İstanbul'un genel görünümü, sarayları, camileri, bahçeleri yanında dönemin Türk toplumunun yapısı ve günlük hayatın çeşitli yönleri hakkında oldukça detaylı bilgiler bulunmaktadır. Örneğin; seyahatnamede Aya Sofya'nın bir plan şeması da yer almaktadır (Grelot, 1680: 108).

Bu çalışmada, İstanbul'u konu alan 17., 18., 19., 20. yüzyıl Batılı ve Türk ressamların resimleri arasından tarihi dokuyu barındıran Eminönü, Tophane, Üsküdar semtlerini konu alan resimler seçilmiş, bu resimlerin konu edindiği mekanlar incelenmiş, aynı mekanların aynı dönemdeki fotoğraf çalışmaları ve günümüzdeki durumu ile karşılaştırmaları yapılmış, sonuçta bu resim örneklerinin, kentsel bellek konusuna bizleri yönlendirmesiyle beraber sonrasında nasıl yönlendireceği de belirlenmiş bulunmaktadır. İncelenen Batılı ressamlar arasında Vanmour, Hilaire, Ziem, Preziosi, Corrodi, Zonaro ve Bardin yer almaktadır. İncelenen Türk ressamlar arasında ise Hoca Ali Rıza, Ahmet Ziya Akbulut, İbrahim Çallı, Hikmet Onat, Nazlı Ecevit yer almaktadır.

Öncelikle 17.yüzyıl ve 19. yüzyıllar arasında resim sanatında Doğu teması, İstanbul'un resim sanatına konu edilmesi ve Oryantalizm konusu araştırıımış, üçüncü bölümde kronolojik sıralamaya göre Batıı ressamların resim örnekleri, dönemin fotoğraf çalışmaları ile karşılaştırılmış ve mekânların günümüzdeki durumları yerinde incelenmiş, görsel olarak belgelenmiş ve günümüzdeki durumları ile karşılaştırılmıştır. Dördüncü bölümde yine kronolojik sıralamaya göre Türk ressamlardan seçilen örnekler günümüzdeki durumları ile karşılaştırılarak mekânların gelişim ve değişimleri belirlenmiştir. Beşinci bölümde ise elde 
edilen bulgular belirtilmiş olup; kentsel belleğin oluşumunda resim sanatı örneklerinin yeri ve önemi belirlenmiştir. Hiç kuşkusuz resimlerinde İstanbul'u konu alan çok sayıda Batılı ve Türk ressam bulunmaktadır. Bu çalışma kapsamında seçilen ressamlar ve bu ressamların resimlerinin seçilmesinde, kentsel bellek başka bir diğer deyişle toplumsal bellek açısından tarihsel süreçteki gelişim ve değişimi bizlere en iyi şekilde sunan ressam ve örnekler ele alınmış, bu seçimin yapıımasında ayrıca resimlere konu olan mekânların günümüzdeki durumlarının da belgelenebilmesi, resim ve dönemin çekilmiş fotoğrafları ile karşılaştırılmalarının yapılması, böylece mekânsal değişimlerin belirlenmesi amaç edinilmiş olduğundan, bu araştırmaya imkân verecek örnekler tespit edilerek çalışma yapılmıştır.

\section{17. VE 20.YÜZYILLAR ARASINDA SANATTA DOĞU TEMASI, ISTANBUL VE ORYANTALIZM}

Avrupa kıtasından Asya kıtasına bir köprü görevi gören Küçük Asya binlerce yıl içerisinde birbirinden farklı ya da devamı niteliğinde olan birçok uygarlığı bünyesinde barındırmış ve çeşitli kültürlere ev sahipliği yapmıştır. Bu kültür çeşitliliğinin kendi içerisinde barındırdığı zıtıkların bir uyum içerisinde bulunması Batııların gizli bir hayranlık duymasına ve Batı dünyasında merak oluşmasına sebep olmuştur. Bu dönemde Batının Doğuya ve Osmanlı'ya yönelik ilgisi de dikkat çekicidir. Bu merak beraberinde ressam gezginlerin, mimarların, coğrafyacıların, kültür elçilerin, yazarların Anadolu topraklarına gelerek roman, hikâye, resim, seyahatname gibi eserlerin üretimine katkı sağlamıştır. Özellikle 17.yüzyıl ile 20.yüzyıllar arasında resim sanatında üretilen eserlerin miktarı dikkate değerdir. Fransa'da 16. ve 18. yüzyıllar arası Türk sanatı ve kültüründen etkilenerek oryantalist bir akım olarak gelişen "Turqueri” modası, Batının Doğu ilgisini açıkça ortaya koymaktadır. Resim, edebiyat ve moda gibi alanlarda bu akım etkisini göstermiştir. Örneğin; Rembrandt ve Rubens gibi ünlü ressamlar Doğu ve Türk imgelerini resimlerinde konu almıştır. Binbirgece Masalları Paris'te Antoine Galland'ın çevirisi ile yayınlanmış, 1782'de Mozart "Saraydan Kız Kaçırma" operasını yazmıştır. Fransız aristokratlarının Osmanlı kıyafetleri içerisinde çok sayıda resim yaptırdıkları da görülmektedir. 18. yüzyılda tarih ve klasik döneme olan ilginin canlanması Batılı aydınların gözlerini Doğuya çevirmelerine neden olmuştur. Çok sayıda Batılı elçi ve gezgin içlerindeki macera duygusunun da etkisiyle Osmanlı topraklarına özellikle de İstanbul'a gelerek incelemelerde bulunmuşlardır. Bu gezilere çoğu zaman Batılı ressamlar da eşlik etmiştir. Antoine- Ignace Melling, Fausto Zonaro, Leonardo Mango, Salvatore Valeri, Jean Leon Geromé, Jean Baptiste Hilaire gibi ressamların çalışmaları sayesinde bu gezilerin sonucunda İstanbul'u konu alan albümler hazırlanmıştır. Örneğin, Hilaire'in İstanbul evlerini resmettiği desenleri 1787 yılında Paris'te basılan “Tableau Général de l'Empire Ottoman” isimli kitapta yer almıştır (Demirarslan, 2016:107).

Resim sanatında ağılıklı tema olarak İstanbul'un panoramik tasviri dışında, sokakları, saray ve çevresi, harem, Üsküdar ve Boğaz betimlenmiştir. Bu yüzyıllar arasında İstanbul'a gelmiş ve İstanbul Boğazı ve çevresini resmetmiş ressamların resimlerinde bulunan mekânların zaman içerisinde geçirdiği farklılaşmayı, kitle kültüründe kültürel belleğin nasıl oluştuğunu seçilmiş örnekler üzerinden görebiliriz.

Osmanlı toplumu devlet dairelerini, saray çevresini Avrupaileştirmeye başlamış, sedir ve divanların yerini koltuk ve sandalye almış, alaturka müzik hor görülmeye başlanmış, Avrupai kıyafetler giyilmiş ve toplum içerisinde yeni modalar ortaya çıkmaya başlamıştır.(Özcan, 1995, 14) Dolayısıyla, batııların ilgisini çeken mistik kültürün kaybolacağı düşüncesi endişe yaratmıştır. Görmek istedikleri kendileri gibi olan değil; tamamen kendilerinden farklı olan bir kültür yapısı idi. Avrupa'da yaşanan Barok döneminin içerisinde insanlar yavaş yavaş eğlence hayatına, kır gezintilerine, oyun, balo 
ve bayramlara merak salmakta, bu da sonrasında gelecek olan Rokoko döneminin de haberini vermekteydi. Bu merak beraberinde birçok gezginin Doğu'ya yani kendilerine en yakın olan Osmanlı topraklarına gelmelerine ve seyahatnamelerini kaleme almalarına da vesile olmuştur. Auguste Boppe "18. Yüzyıl Boğaziçi Ressamları" kitabında (1998: 3) yaz aylarında Belgrad ormanındaki köylerde sürülen yaşamı Hollandalı bir gezginin doğu hatıraları ve maceralarını kaleme aldığı kitabının bir bölümünden anılarına şöyle yer vermiştir:

"Ne kadar önemli İngiliz ve Fransız varsa hepsi ordadırlar. Özellikle, şehirde bir tutsak hayatı süren kadınlar burada keyiflerine göre yaşıyorlar. Bayramlar, eğlenceler o kadar sık birbirini kovalıyor ki nasıl akıp gittiği hissedilmiyor. Bazı günler Karadeniz kıyılarına gidilir, kurulan büyük çadırların altındaki muhteşem sofralarda lezzetli yemekler sunulur, kıyıya çarpan denizin sesi, müziğin sesiyle karışarak, iştahları daha da arttırır. Bazı günlerse Belgrad bentlerine gidilir. Yumuşak rahat divanlara uzanılır, tatı bir meltem sizi keyifli bir uykuya sürükler. Su kemerleri ayrı bir eğlencedir. Bütün gün oyunlar, eğlenceler birbirini kovalar. Gün can sıkıntısı nedir bilmeden uçup gider."

Belgrad ormanlarındaki bu eğlence günlerce sürüp giderken bir yandan da ormandaki vahşi hayvanlardan daha çok Türklere karşı olan korkuları da dikkat çekicidir.

Yalnız Avrupalılar Türkleri merak etmiyor, Türkler de Batı'yı merak ediyor ve onları daha iyi tanıyabilmek için elçi gönderiyorlardı. Özellikle III. Selim döneminde Avrupa kültürü iyi tanındı. Matbaanın gelişi ile birlikte Kâğıthane yamaçları zarif altın yaldızlı veya renkli boyalı ahşap evlerle bezendi. Kağıthane'deki büyük değişim III.Ahmed'in çok hoşuna gitti ki buranın adını mutluluk ülkesi anlamına gelen Sa'dabat olarak değiştirdi (Boppe, 1998: 4)..

Batılıların, Doğu olarak kastettikleri, Osmanlı İmparatorluğu ve Türklerdir. Başka bir anlatımla Türkiye başta olmak üzere o dönemde Osmanlı toprağı olan Mısır, Suriye, Lübnan, Kutsal topraklar ya da kısaca Müslüman olan Akdeniz ülkelerini kapsar ki, o dönemde doğu gezisine çıkan önemli kişiler, saray erkânı, bilginler mutlaka İstanbul'da Vanmor'un atölyesine uğrar ve doğulu kıyafetler içerisinde portrelerini yaptırırlardı (Boppe, 1998, 13-14) ve o dönem içerisinde Türk gibi giyinmek Avrupa'da moda olmuş, Carle Van Loo uzun yıllar Roma'da kaldıktan sonra 1736 yılında Paris'e dönmüş ve dönemin modasına uyarak figürlerine Türk kıyafetleri giydirmiştir. (Demirsar Arlı, 2000, 61)

\section{BATILI RESSAMLARIN RESIMLERINDE ISTANBUL TASVIRLERI VE KENTSEL BELLEK}

Kentsel bellek açısından bir inceleme söz konusu ise İstanbul'a gelen ve gelmeyen ressamların resimlerinin gerçekliği üzerinde durulması gereken bir konudur. Osmanlı topraklarını ziyaret eden Batılı ressamlar ile ilgili yazılı kaynakların (Boppe, 1998; Demirsar Arlı, 2000) incelenmesi sonucunda İstanbul'u resimlerinde konu alan ressamları ve bu yabancı ressamların yapmış olduğu resimleri çeşitli gruplara ayırmamız mümkündür. Öncelikle bu ressamları İstanbul'a gelen ve gelmeyen ressamlar olarak iki gruba ayırabiliriz.

17. yüzyıl süresince İngiltere, Hollanda, İsveç, Fransa ve Avusturya gibi ülkelerin Osmanlı İmparatorluğu'nu daha iyi tanımaları için gönderdikleri elçi heyetleri, imparatorluğun günlük yaşantısı, devlet örgütü ve saray düzeni ile ilgili birçok bilgi toplamış, yanlarında getirdikleri ressamlara belgeleyici resimler yaptırmışlardır. $\mathrm{Bu}$ elçiler arasında Hollanda'dan gelenlerin, yanlarında götürdükleri çok sayıda Türk eseri, Türk kültürüne ait olan kılık, kıyafet ve diğer kültürel öğeleri edinerek oluşturdukları kompozisyonları içeren resimlerden oluşur. Bu eserler Rembrant ve Rubens gibi İstanbul'a gelmeyen birçok 
Mimarlık ve Yaşam Dergisi Cilt: 2, No: 1, 2017 (121-151)

Deniz DEMIRARSLAN, Begüm SAVCIN

ressama esin kaynağı olmuştur. Bu resimlerde var olan mekânlar tamamen hayali mekânlardır.

Diğer taraftan İstanbul'a gelen ressamları tekrar gruplamamı gerekmektedir. Onu da şu şekilde ifade edebiliriz: Illk grup, İstanbul ve Anadolu topraklarına gelip, buralarda çeşitli taslak, eskiz ve krokileri yanlarında götürerek, kendi yorumlarını yani hayallerini ekleyerek idealize edilmiş İstanbul dekoru oluşturup resmedenler. İkinci grup, İstanbul ve Anadolu topraklarına gelip doğa karşısında eskiz ve resimlerini yapan ancak; bu kompozisyon içerisinde gerçekte var olan mekânlara ekleme veya çıkarma yapanlar. Son olarak üçüncü grup ise; tamamen direkt doğa karşısında yorumsuz betimleme yapan ressamlardır. Bu ressamlar da kendi içerisinde iki gruba ayrılmaktadır: İlki bu grupta bulunan ressamlar genellikle gezgin ressamlar olmaktadır. Özellikle arşivleme yapmak, bilgi iletmek için devlet tarafından ya yalnız gönderilmekte ya da bir seyyahla birlikte gelmekteydiler. İkinci grup ise tamamen kendi hür iradeleriyle gelip doğayı gördükleri, olduğu gibi resmedenlerdir. Bugün kültürel bellek çalışmaları için bize en doğru bilgiyi son gruptaki ressamların çalışmaları vermektedir.

$\mathrm{Bu}$ bölümde Batılı ressamların gözünden İstanbul tasvirleri kentsel bellek açısından kronolojik sıralamaya göre incelenmiştir. Seçilen Batılı ressamlar ve İstanbul'u konu alan resimleri sırasıyla Vanmour, Hilaire, Ziem, Preziosi, Corrodi, Zonaro ve Bardin'dir.

\subsection{Jean-Baptiste Vanmour'un eserinde İstanbul tasviri ve kentsel bellek}

Jean-Baptiste Vanmour'dan (1671- 1737) önce Osmanlı topraklarına birçok ressam, ressam gezgin gelmiş olmasına rağmen II. Mahmud'un reformları ile artık kaybolmaya başlayan eski Türkiye'nin son anılarını bize sunan, Boğaziçi'nin unutulmaz ressamı Antoine Ignace Melling'e kadar sayısız sanatçı İstanbul'da kısa süre kalmıştır. Sadece Vanmour, bu topraklarda en uzun süre kalmış ve burada vefat etmiştir (Boppe, 1998: 3). Vanmour, Lale Devri'nin en önemli tanıklarından biridir. İstanbul'a geldiği 1699 senesi Osmanlı Devleti'nin Batı'ya açılış sürecinde bir dönüm noktasıdır. Bu dönem içerisinde fotoğraf makinesi henüz icat edilmediği için Vanmour'un yapmış olduğu resimler bir sanat eserinden ziyade, Avrupalılar için bir belge niteliği taşımaktaydı. Altmış yıl gibi bir süre içerisinde İstanbul'da yaşamış olan Vanmour saray ve çevresinde dostluklar edinmiştir. Vanmour dedikoduyu sevmeyen bir insan olduğu için güven kazanmış ve birçok devlet adamının ziyafet sofralarına konuk olmuştur. (Boppe, 1998, 9-10) Vanmour, çok sayıda elçi kabul törenleri, İstanbul görünümleri, portreler, Patrona Halil isyanı gibi siyasi ve toplumsal olaylar ve gündelik yaşam sahneleri resmetmiştir. Vanmour'un en belirgin özelliği resimlerini büyük bir gerçekçilik ile yapmasıdır. En anıtsal boyutlu resmi olan "İstanbul panoraması" Pera'daki Hollanda Büyükelçiliği'nin bahçesinden çizilmiş olmalıdır. Bu resimde Topkapı Sarayı, Ayasofya, Sultanahmed camii ve günümüzde olmayan Yalı ve Sepetçiler Köşkü yer almaktadır (Makzume ve Kocabaşoğlu, 2004: 122). Dolayısıyla çalışma önemli bir belgesel niteliği taşımaktadır (Şekil 1). 


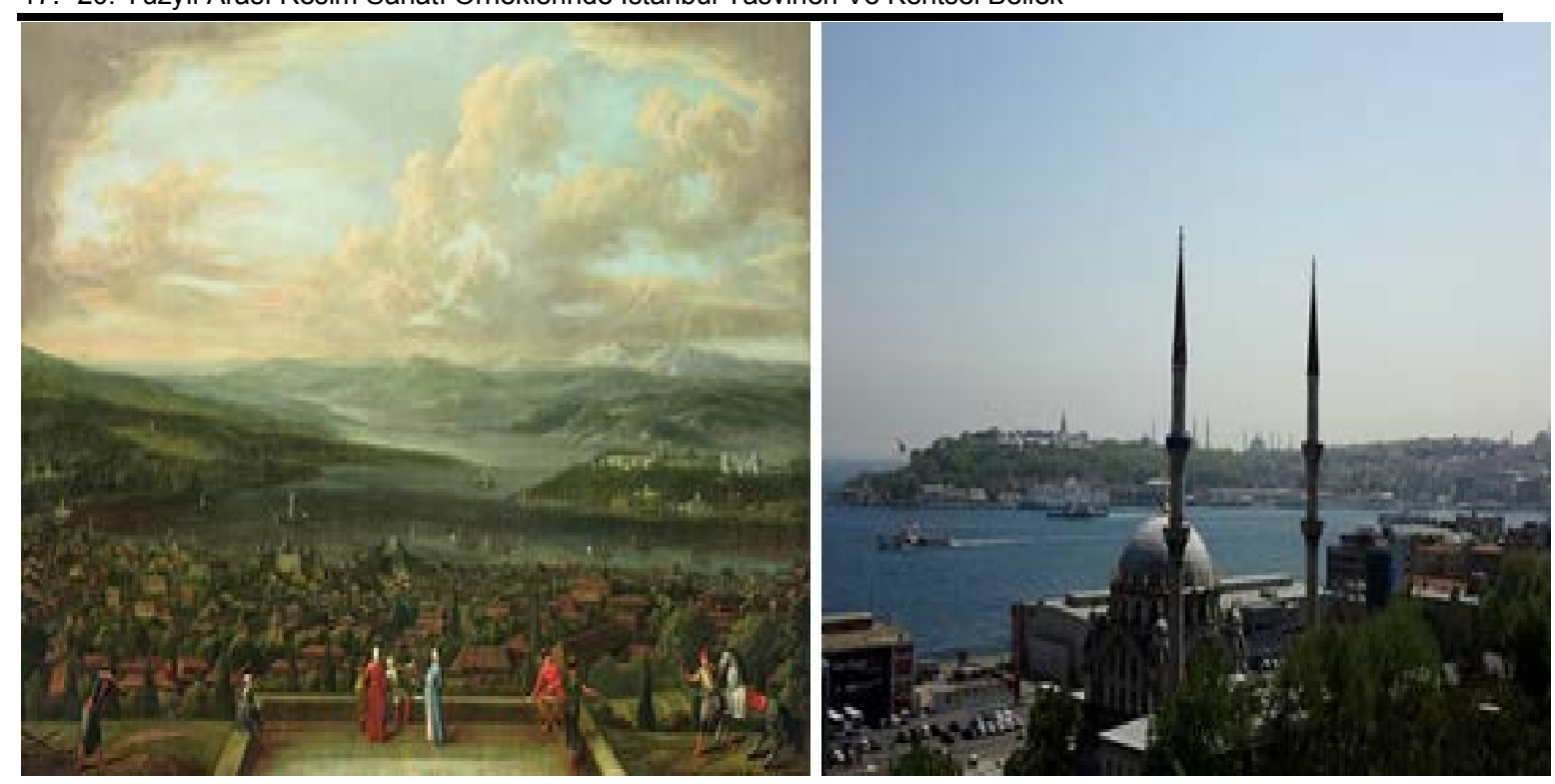

Şekil 1: Jean Baptiste Vanmour "istanbul panoraması” (URL-4) ve (URL-4a)günümüzde yakın bölgeden panorama.

Çalışma kapsamında XIV.Louis tarafından "Kralın Doğu'daki Ressamı" olarak isimlendirilen Vanmour'un incelenen bir diğer resmi de 1720 - 1737 yıllarına tarihlendirilen "Başvezir alayının at meydanından geçişi" isimli tablodur (Şekil 2). Resim, günümüzde Amsterdam Rijksmuseum'da sergilenmektedir. Lale Devri'ni en iyi gözlemleyen ve anlatan sanatçılardan biri olan Vanmour'un incelenen eserinde Sultanahmed Meydanı ve Sultanahmed Camii konu edilmektedir. Caminin cephe, son cemaat yerini örten kubbeler gibi gibi mimari özellikler açısından yorumlanarak resmedildiği görülmektedir. Dikilitaşlar, cami ve meydan ilişkisi de gerçeğe yakın şekilde tasvir edilmiştir. Buradan da anlaşılacağı üzere Vanmour muhakkak ki Sultanahmed Meydanı'nı ziyaret etmiş, eskizler çalışmış, ancak tabloyu yaparken kendi yorumlarını da katmıştır. Makzume ve Kocabaşoğlu eserlerinde (2004:123) sanatçının belli bir sahneyi resmederken yerinde çizimler yaptığı, ancak daha sonra atölyesinde bazı ayrıntıları değiştirdiği, ayrıca her zaman elinde bir veya birkaç figürden oluşan desenlerin bulunduğunu ve bunlardan büyük kompozisyonlarında yararlandığını, ayrıca sipariş aldığı müşterilerinin portrelerinden de bu tablolarında yararlandığını belirtmektedirler. Büyük olasılıkla Vanmour bu eserinde Sultanahmed Camii'ni atölyesinde resmederken yorumlamıştır. 

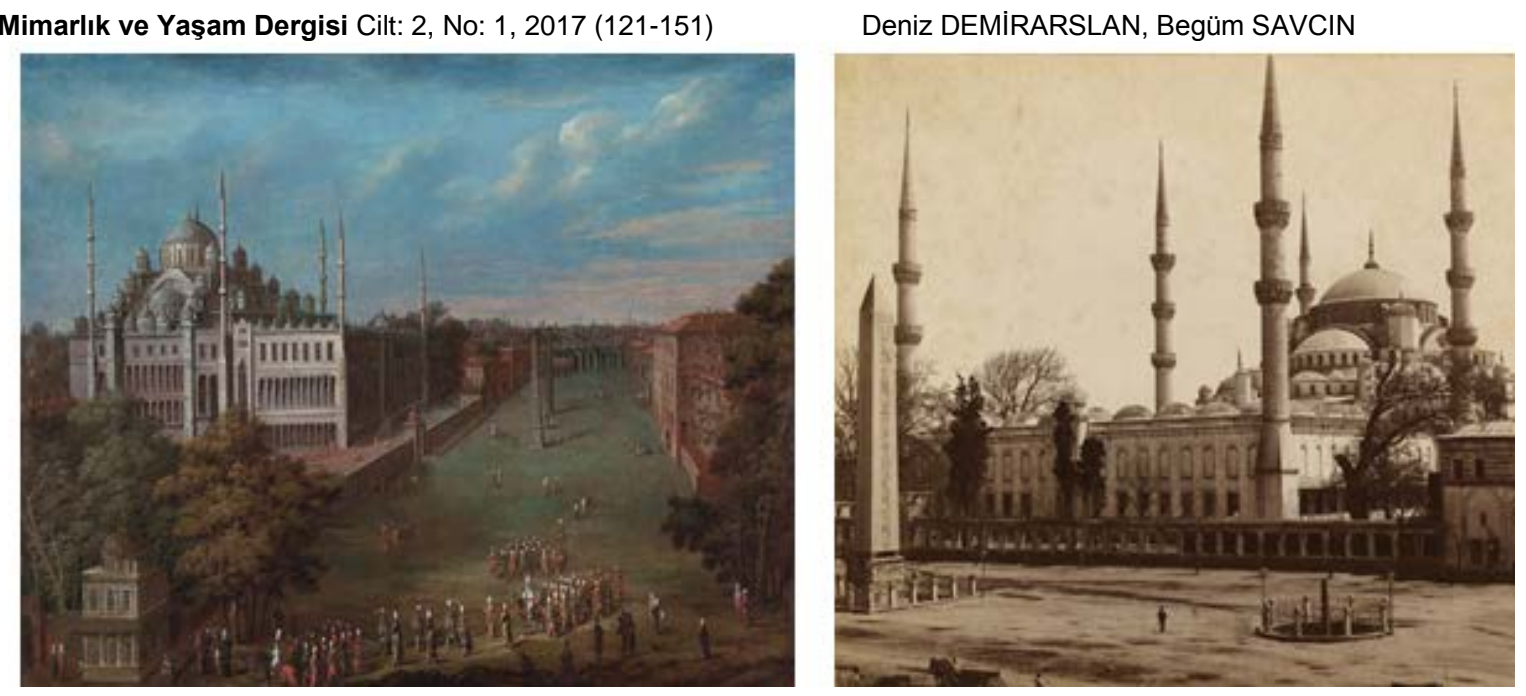

Şekil 2: Vanmour "Başvezir alayının at meydanından geçişi" (Demirsar, 2000: 42-43) ve meydanın Ali Rıza Paşa tarafından çekilmiş fotoğrafı (URL-5).

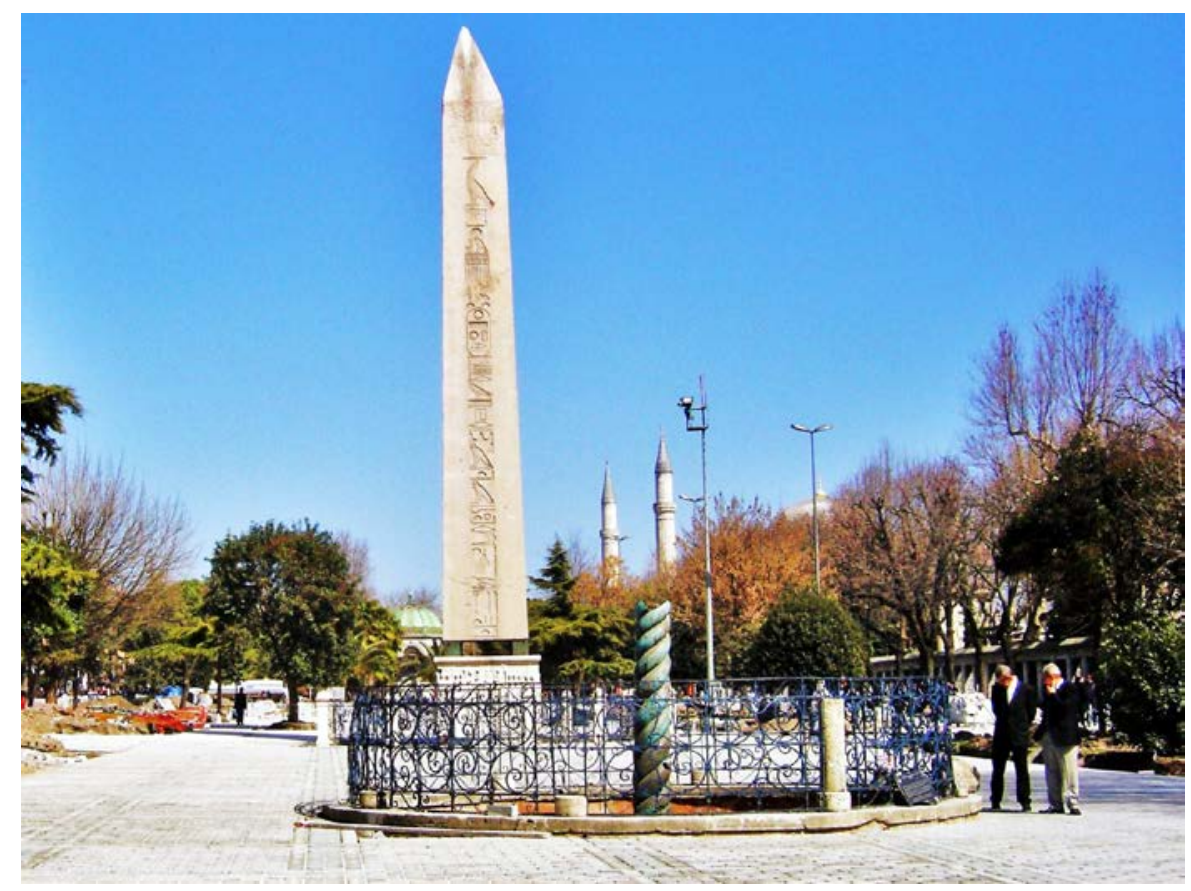

Şekil 3: At Meydanı'nın günümüzdeki durumu (URL-5a).

\subsection{Jean Baptiste Hilaire'in eserinde İstanbul tasviri ve kentsel bellek}

Osmanlı topraklarına birçok sebeple gelen ressamlardan biri de Jean Baptiste Hilaire'dir (1753- 1822). Hilaire, İstanbul büyükelçisi Kont Marie-Gabriel-Florent-Auguste de Choiseul-Gouffier ve bir grup ressamla birlikte 1776 yılında Ege gezisine çıkmış, 1782 yılında bu gezinin sonucu olarak bir kitap yayınlanmıştır. Daha sonra Choiseul-Gouffier, Cassas ile birlikte Hilaire'i İstanbul'a davet etmiş ve her iki sanatçı Osmanlı topraklarında gerek İstanbul betimlemeleri ile birlikte oryantalizmin temel konusu olan "doğu" temalı birçok resim, gravür ve suluboya resim yapmışlardır (Kıbrıs, 2014: 125). Hilaire'e ait incelenen resim Yeni Cami ve İstanbul Limanı'nı konu almaktadır (Şekil 4). Resim 1789 yılında yapılmıştır. Dolayısıyla Galata Köprüsü henüz inşa edilmemiştir. Hilaire'in resmi yapmış olduğu açıdan günümüzde aynı bölge yeniden incelenmiş ve fotoğraflanmıştır. 
Mekânın günümüzdeki durumu ile karşılaştırıldığında resimde birbirinden farklı boyutlarda görülen yelkenlilerin yerine bugün şehir hatlarına ait yolcu vapuru Yeni Cami'nin önündeki iskelede bulunmaktadır. İstanbul Limanı olarak isimlendirilen Karaköy limanında bugün yine şehir hatlarına ait vapur iskelesi bulunmaktadır. Eminönü ve çevresinde bulunan Osmanlı yapısı olarak da bilinen ahşap evlerin yerini bugün beton yapılar almıştır. Hilaire'in resminde siluette görülen camiler de mevcudu göstermekte olduğundan Hilaire'in eserinde gerçekçi bir İstanbul betimlemesi yaptığını söylemek mümkündür.
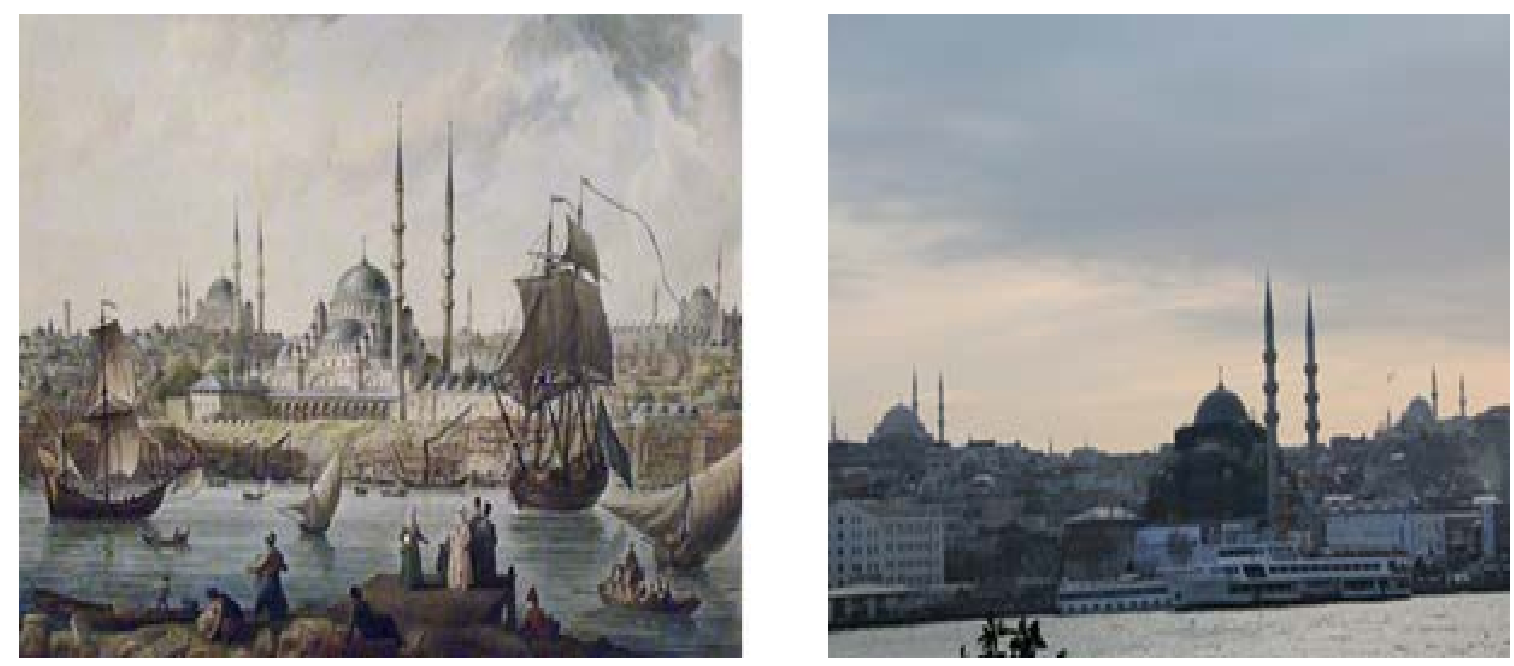

Şekil 4: Solda Hilaire'in resminde Yeni Camii ve çevresi (Kıbrıs, 2014:138), sağda ise (Foto.1: E.Begüm Savçın) Yeni Camii ve çevresinin günümüzdeki durumu (URL-6).

Resmin detayına bakıldığı zaman bir grup yerli ve yabancının tarihi eserleri gemiye yüklemek üzere kayıklara aktardığını görmekteyiz. Hilaire, bu resmin altına "antik eserlerin yüklenmesi” yazmıştır. Çünkü resimde o dönem Fransız Büyükelçisi Choiseul-Gouffier'in topladığı eserlerin gemiye yüklenmesi konu edilmektedir. Ertuğrul Günay, Kültür Bakanlığı sırasında Elçiler ve Ressamlar Sergisi'nde gördüğü bu resmi delil gösterip suç duyurusunda bulunmuştur (URL-7). Dolayısıyla Hilaire'in resmi toplumsal bellek açısından büyük önem taşımaktadır (Şekil 5).

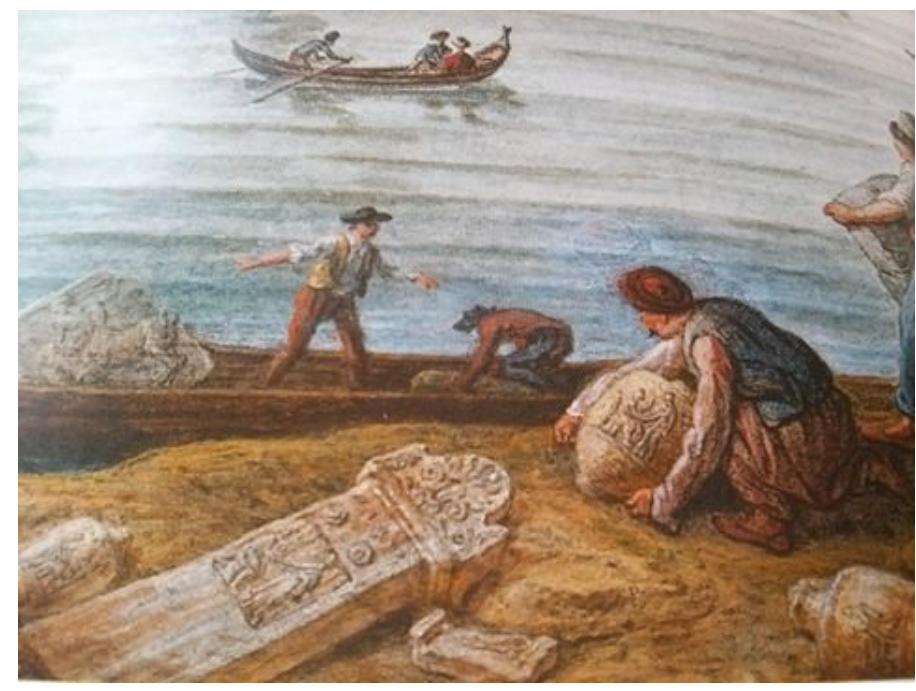

Şekil 5: Hilaire'in resminden detay incelemesinde Osmanlı'da tarihi eserlerin Batılılar tarafından kaçırılması görülmektedir. 


\subsection{Félix Ziem'in eserinde İstanbul tasviri ve kentsel bellek}

Barbizon ekolünden bir peyzaj ressamı olan Ziem (1821-1911) Venedik, Marsilya, Rodos, İstanbul, İzmir, İskenderiye, Şam ve Beyrut gibi şehirlere yaptığı gezilerden edindiği izlenimleri tablolarına yansıtmıştır. Meslek yaşamı boyunca en az 10 bin desen, 6 bin yağlıboya yaptığı düşünülür. Özellikle Venedik ve İstanbul tabloları ile tanınmıştır. Ziem, 1855 yılında kaleme aldığı günlüğünde İstanbul'a gelme tasarısı ile ilgili, "Bu yolculuğun belirgin ve güçlü biçimlerin yoğunluğuyla ışı ışıl resimler yapma dileğimi de destekleyeceğini umuyorum" notunu düşer. Paris Anlaşmasının imzalanmasından üç ay sonra, 10 Temmuz 1855'de Marsilya'yla İstanbul'u birbirine bağlayan Messageries Maritimes'in buharlı gemisi Le Danube'e biner. 18 Temmuz 1855'de İstanbul'a varır ve iki ay kalır. Ziem farkıı bir sanatçıdır, özgünlükten yanadır. Yapıtları incelendiğinde, herkesin gittiği yerlere gitmek istememesi dikkat çeker. Ziem, kentin canlı bölgeleriyle çok ilgilidir. Giysiler, insanlar, kocaman öküzlerin çektiği arabalar, köpekler, Boğaz ve Haliç sularında kayıp giden yelkenliler, kayıklar başlıca esin kaynaklarıdır. Doğu'nun görkemi, masalsı mimariler, suyun gürül gürül aktığı çeşmeler gibi basmakalıp düşüncelerden uzaktır. Sanatçının İstanbul'da kaldığı süreçte kaç desen yaptığı tam olarak bilinmese de, Ziem Müzesi'nde korunan 43 defterden ikisi Türkiye'yle ilgilidir (URL-8). Sanatçının eserleri incelendiğinde her ne kadar gerçekçi çalışmış gibi durmakla beraber resmederken kendi hayal gücünü de katmıştır. Bunun sebebi ise ressamın İstanbul'da bulunduğu süre içinde Boğaz'ın, kayıkların, Osmanlı giysili figürlerin, günlük hayatın, mimari yapıtların ve İstanbul'u tanımlayan birçok unsurun karakalem ve çini mürekkepli eskiz çalışmalarını yapmış ve Fransa'daki atölyesine döndüğünde resmetmiş olması olarak gösterilebilir. Ayrıca Ziem, gezdiği yerleri ve insanları ayrıntılı bir şekilde resmetme düşüncesi yerine izlenim ve renk arayışı içindeydi. Ziem'e göre bir resmin göze hitap etmesi ve ruha seslenmesi ancak ressamın kendi idealizminin realizm ile sentezinden oluşması gerekiyordu (Makzume, 2004:59).

Ziem'in Yeni Cami'yi konu alan resmi incelendiğinde cami denizden resmedilmiştir (Şekil 6). Kayıklar diğer resimlerinde olduğu gibi resimde önemli unsurlar olarak göze çarpmaktadır. Caminin yapı malzemesi kesme küfeki taşı, mermer ve tuğladır. Resimde de bu malzeme dokusu ve renkleri kendini yansıtmaktadır. Cami mekânına biri kuzeyde revaklı avluya açılan, ikisi yanlarda bulunan üç kapıdan geçilerek ulaşılır; ayrıca mihrap yönünde yanlarda birer küçük kapı daha bulunur. Ancak kentsel bellek açısından incelendiğinde camii hemen denizin kıyısındadır ve cami mimari özellikleri dikkate alındığında gerçeği tam olarak yansıtmamaktadır. Dolayısıyla özgünlükten yana bir sanatçı olan Ziem'in eserinde kendi yorumunu katmış olması büyük bir olasılıktır. Çevrenin o tarihteki görünümü ile günümüzdeki görünümü arasında da yapılaşma açısından önemli bir farklılık gözlenmektedir. Cami deniz kenarına inşa edilmiştir ancak denizle mesafesi sonradan denizin doldurulması sonucu artmıştır. Resim de bize caminin deniz kenarında yapılmış olduğunu kanıtlamaktadır. Zira caminin ilk mimarı Davut Ağa, caminin temelleri atıırken bolca su çıkması üzerine gece gündüz çalışarak tulumbalarla suyu boşaltmış ve kazıklar üzerine Rodos'tan getirilen taşları atarak duvarları yer seviyesinden yükseltmeyi başarmıştır (Şafak, 2013: 88).

Öte yandan Ziem'in İstanbul'u konu alan bir başka tablosu incelendiğinde daha gerçekçi unsurlar göze çarpmaktadır. Göksu Mihrişah Sultan Çeşmesi'ni konu aldığı resminde çeşmeyi oldukça gerçekçi olarak betimlemiştir (Şekil 7). 1850'li yıllarda fotoğraf sanatçıları James Robertson ve Felice Beato tarafından hemen hemen aynı açıdan çekilen fotoğrafta çeşmenin özgün haline benzerliği daha açık bir şekilde belli olmaktadır. 

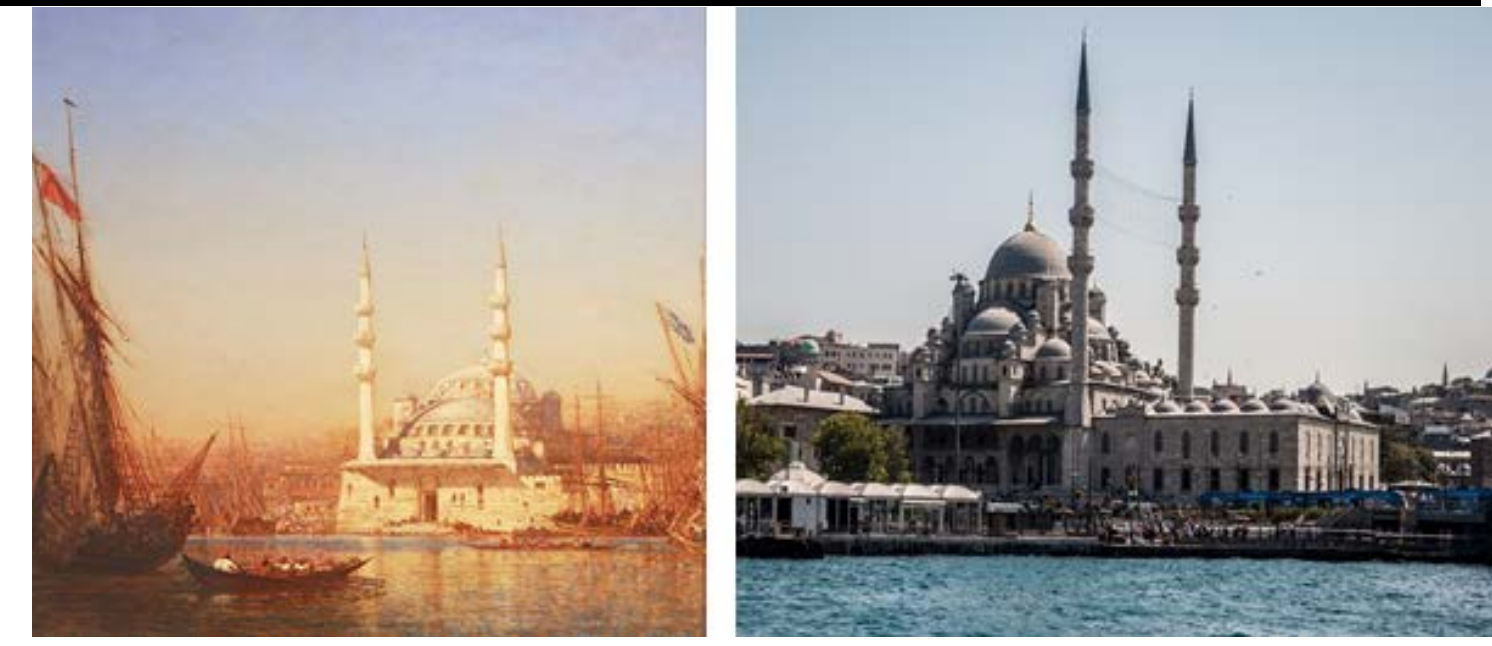

Şekil 6: Ziem'in tablosunda Yeni Camii (URL-9) ve (URL-9a) çevresi ile günümüzdeki durumu.
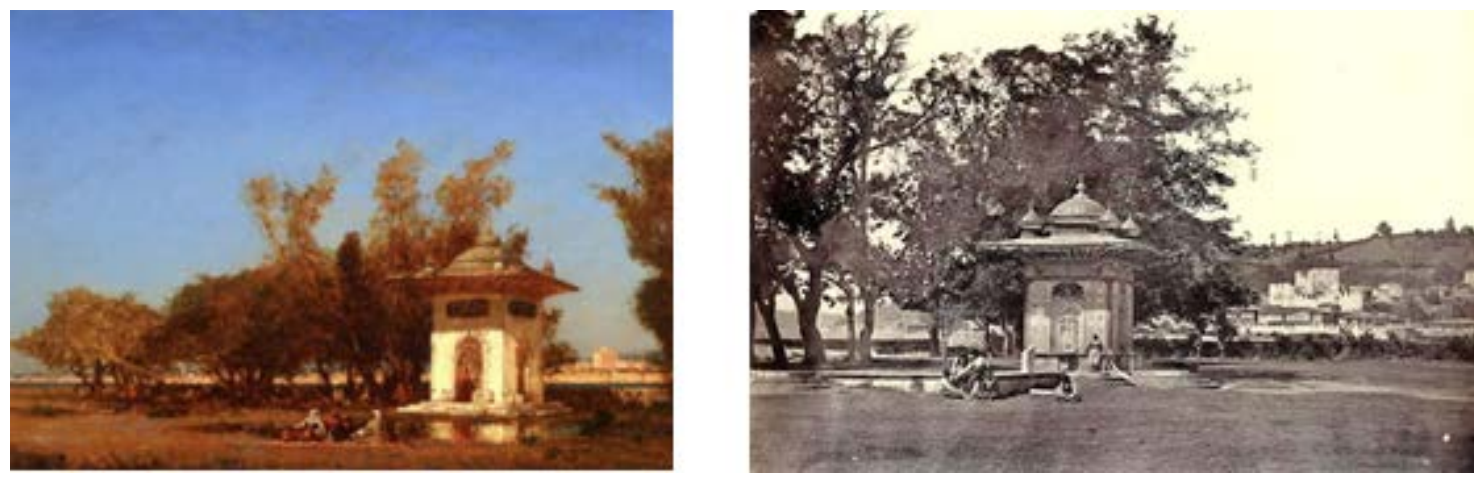

Şekil 7: Felix Ziem'in Mihrişah Sultan Çeşmesi tablosu (URL-10) ve 1850'li yıllarda fotoğraf sanatçısı James Robertson ve Felice Beato tarafından çeşmenin çekilmiş fotoğrafı (URL-11).

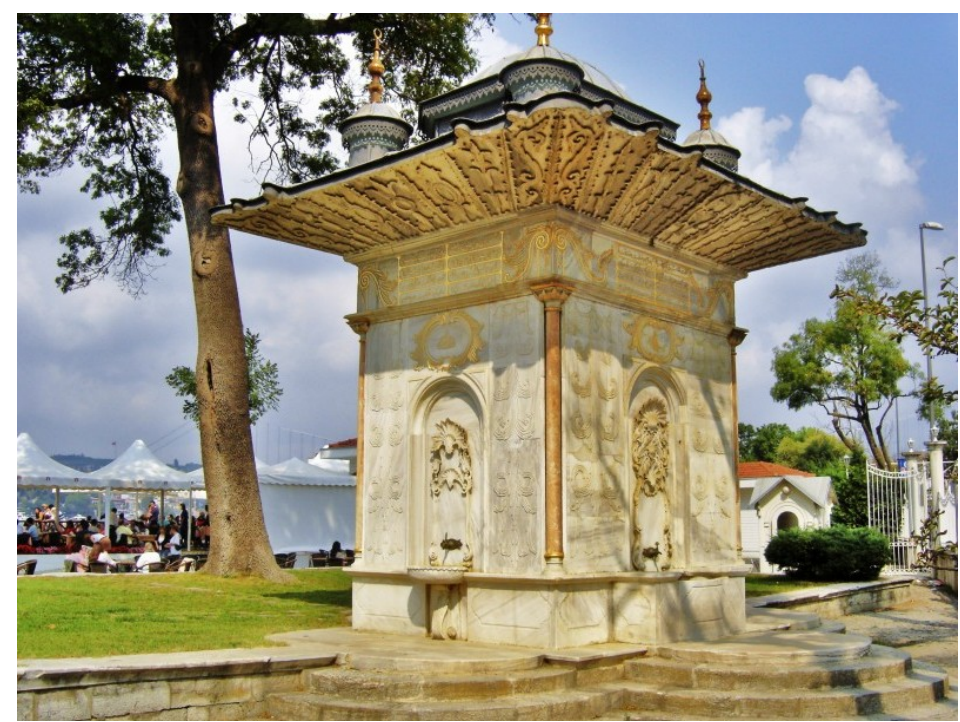

Şekil 8: Göksu Mihrişah Sultan Çeşmesi'nin günümüzdeki durumu (URL-11a). 


\subsection{Amadeo Preziosi'nin eserinde İstanbul tasviri ve kentsel bellek}

Maltalı ressam Preziosi (1816- 1882), 19. yüzyıl içinde henüz otuz dört yaşındayken İstanbul'a gelmiş, burada bir Rum'la evlenmiş, üç kızı bir oğlu olmuştur. Ölene kadar burada yaşamış ve 1882 yılında Yeşilköy'de ava çıktığı zaman kazara kendini yaralamış ve burada ölmüştür. Kendisi Yeşilköy'ün Latin Katolik mezarlığına defnedilmiştir (Berk, 1977: 6-7). Preziosi İstanbul'da yaşadığı süre boyunca birçok esere imza atmıştır. Özellikle suluboya resimleri ustaca yapılmış ve en bilinenleridir. Kendisi doğrudan doğruya doğa ya da model karşısında çalışmalarını yapmıştır. Fakat resimlerindeki mekânlar oldukça kalabalık bir kompozisyon içerir. Çalıştığı konular arasında salt mekân ya da peyzaj yoktur, denizde kayıklar, sokaklarda halkın resimleri kısaca İstanbul'u insansız, insanı İstanbul'suz bırakmaz (Berk, 1977: 7).

Oryantalist bir Boğaz ressamı olan Kont Amadeo Preziosi'nin incelenen resminde tarihi yarımadadan bir mekân betimlemesi yer almaktadır (Resim-9). Resmin, Eminönü'nde günümüzde otobüs duraklarının olduğu noktadan, önde Tahtakale Hasırcılar Çarşısı'nda bulunan Rüstempaşa Camii'nin arkasında bulunan Çemberlitaş Nuruosmaniye Camii'ne doğru bakılarak resmedildiği tahmin edilmektedir. Kompozisyon içerisinde, ressam resmini yapmış olduğu Rüstempaşa Camii'nin ölçüsünü küçültmüş, arkada bulunan Nuruosmaniye Camii'nin ölçüsünü büyütüp, minare sayısını artırmış ve camiyi yapısal olarak yorumlamıştır. Ön sağ tarafta bulunan mimari yapı tarihi bir eser olarak günümüzde resim içerisinde olan yerde değildir. Ancak, James Robertson'un 1854 yılında çektiği Tophane ve Kılıç Ali Paşa Camii'sinin fotoğrafındaki açı ve sağ taraftaki mimari yapının benzerliği dikkat çekicidir (Şekil 10). Salıpazarı olarak da bilinen bölgede satıcıların tezgâhları ve tenteleri, James Robertson'un 1853-1854 tarihli, "Topçular Kışlası Girişi" isimli bir diğer fotoğrafında (Kıbrıs ve Ögel, 2006: 19,29) açıkça görülmektedir. Ressam büyük bir intimalle daha iyi bir etki yaratabilmek için şehir içerisinde birçok tarihi mekânlardan eskiz alıp, bu eskizleri birleştirerek yeni bir kompozisyon oluşturmuş olabilir.
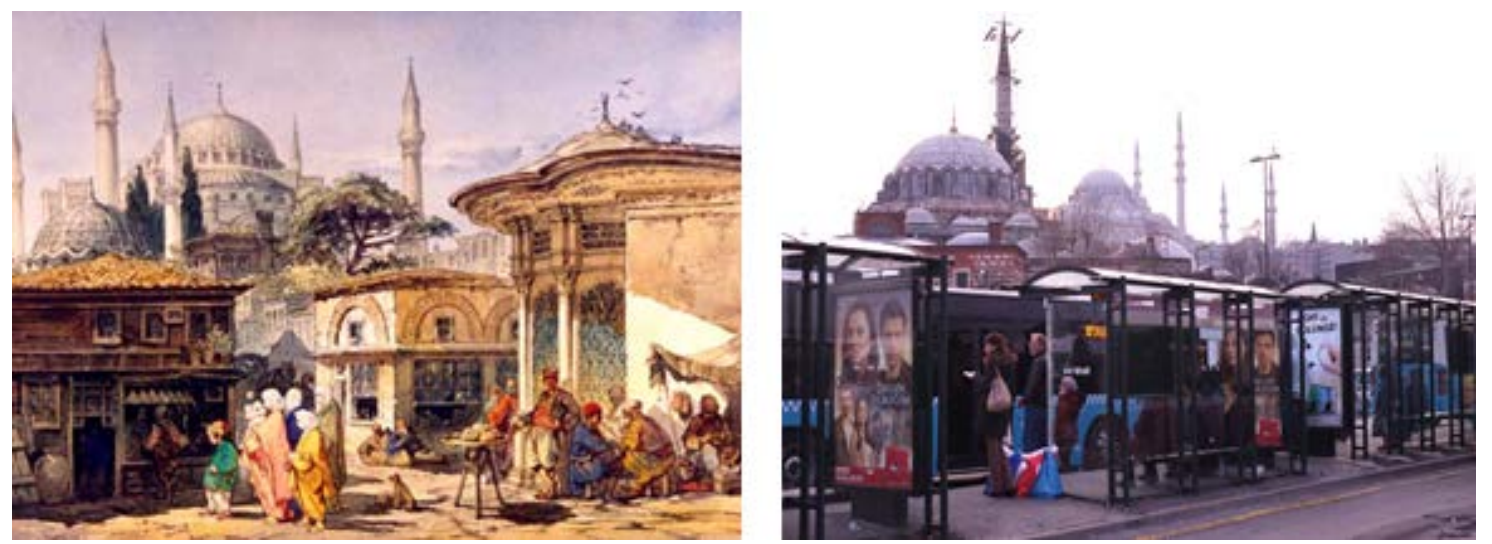

Şekil 9: Preziosi'nin tablosunda (URL-12) Eminönü ve (Foto.2: E.Begüm SAVÇIN) bölgenin benzer bir açıdan bakışta günümüzdeki durumu. 

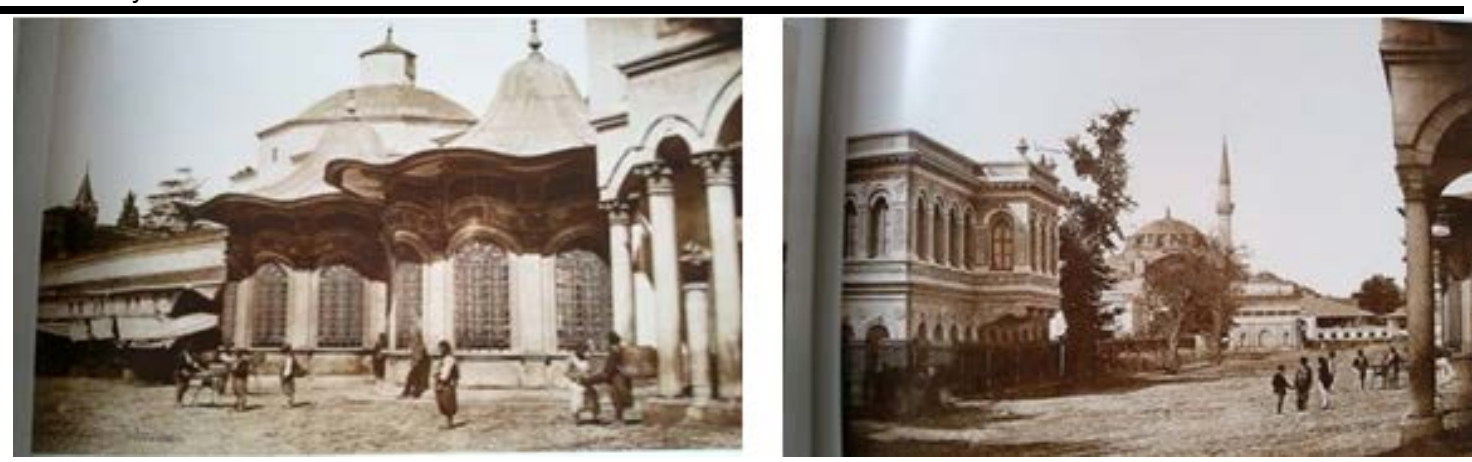

Şekil 10: Fotoğrafçı James Robertson'un fotoğraflarında Preziosi'nin tablosunda bulunan yapılar farklı mekânlarda görülmektedir. Solda Topçular Kışlası girişi 1853- 1854 ve sağda Tophane Kasrı ile Kılıç Ali Paşa Camii görülmektedir 1854 (Kıbrıs ve Ögel, 2006: 19, 29)

\subsection{Hermann Corrodi'nin eserinde İstanbul tasviri ve kentsel bellek}

1844 yılında Frascati'de dünyaya gelen Hermann Corrodi 1872 yılında Paris'e gitmiş ve başta İngiliz Kraliyet ailesi olmak üzere pek çok Avrupa Kraliyet ailesine hizmet etmiştir. Uzun yıllar Roma'da yaşamakla beraber resimleri için malzeme ve fikir edinmek amacıyla seyahat etmiştir. Suriye, Mısır, İstanbul, Kıbrıs gittiği yerler arasındadır. Asıl olarak, akademik tarzda manzara ressamıdır ancak bir kısım eseri 19. yüzyıl Oryantalizm tarzındadır.(URL-13)

Corrodi'nin eseri incelendiğinde; Galata Köprüsü'nün üçüncü Galata Köprüsü olduğu görülmektedir (Şekil 11). Ayrıca resimde görülen Yeni Camii'nin resimdeki açısı günümüzdeki köprü ile olan ilişkisinde benzer açıdan resmedilmiş olup, caminin yeri ve konumu itibariyle doğru tasvir edildiği, ressamın camiyi mimari açıdan yorumladığı, arka siluete ise eklemiş olduğu camiler ile tarihi yarımadanın mistik- doğu kültürü özelliklerini yansıtmak istediği açıkça dikkati çekmektedir. Resim ile yakın tarihlerde çekilmiş eski bir İstanbul fotoğrafında da Galata Köprüsü ve tarihi yarımada ilişkisi gözlemlenmekte ve ressamın resminde yorumlar katmış olduğu daha iyi anlaşılmaktadır. Tablo daha detaylı incelendiğinde ise köprü üzerinde yer alan köpek tasvirleri, 19. Yüzyılda İstanbul sokaklarında sık olarak görülen sokak köpeklerine ilişkin yaşanan sorunların da ispatıdır (Şekil 12, 13).
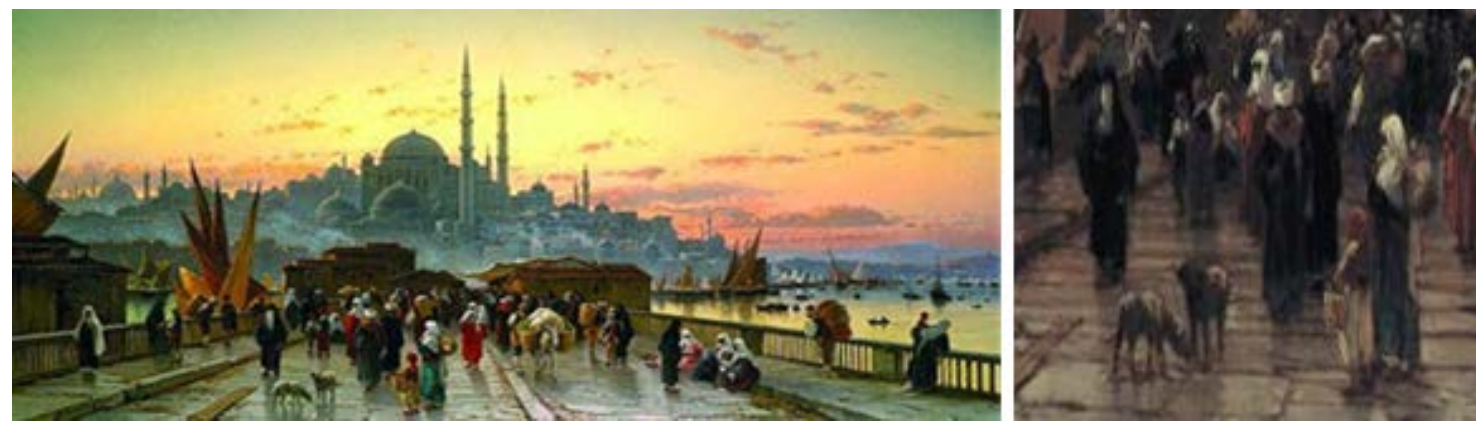

Şekil 11: “Şafakta Galata Köprüsü” (URL-14) ve tablodan detay. 

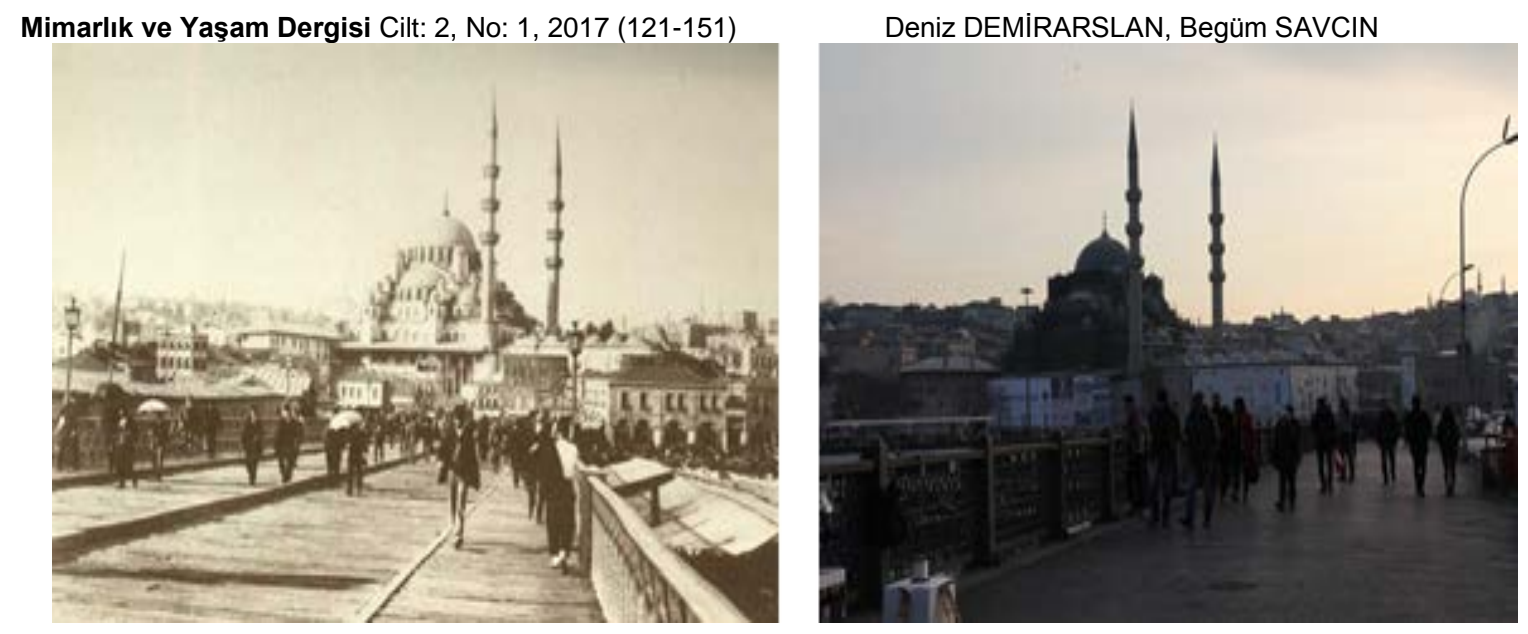

Şekil 12: Eski bir fotoğrafta Galata Köprüsü (URL-15) ve (Foto.3: E.Begüm Savçın) günümüzdeki durumu.
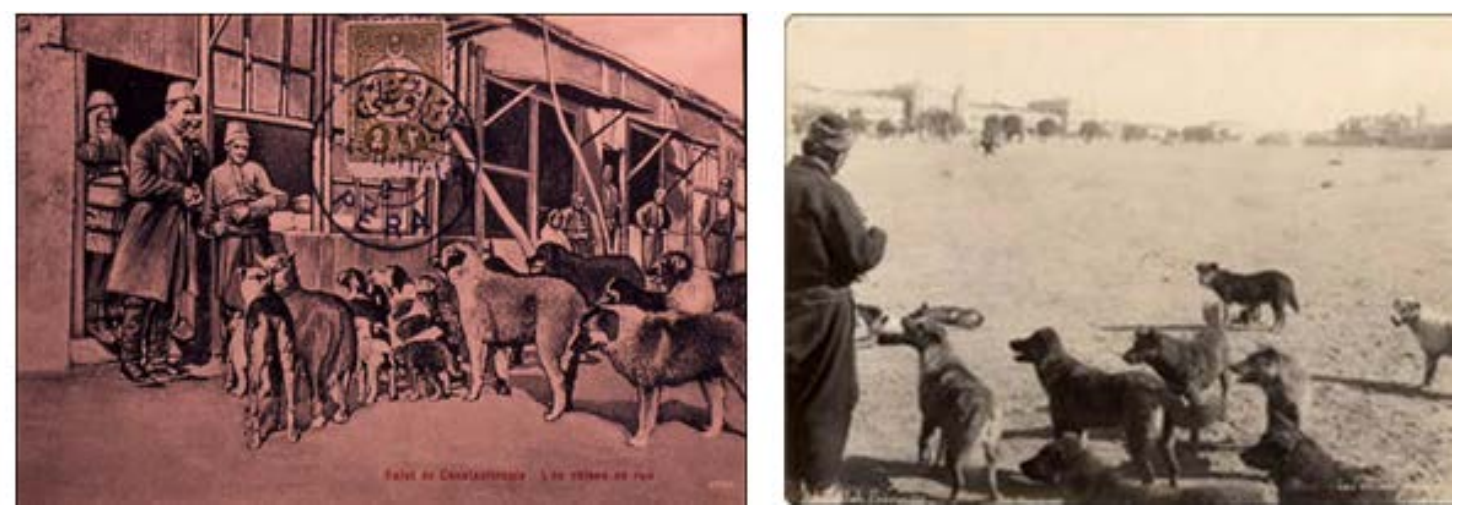

Şekil 13: İstanbul'da Sokak köpeklerini gösteren bir kartpostal ile fotoğraf (URI-16, URL-17)

\subsection{Fausto Zonaro'nun eserinde İstanbul tasviri ve kentsel bellek}

1896 yılında II.Abdülhamid'in saray ressamlığını yapan Fausto Zonaro (1854-1929), Venora ve Paris'te sanat eğitimi görmüştür. İstanbul'a ailesiyle birlikte yerleşen Zonaro, saray ressamı olmadan önce diplomat eşlerine resim dersi vererek geçimini sağlamaktaydı. II.Abdülhamid'e armağan ettiği resim padişah tarafından çok beğenilince saray ressamı olarak çalışmaya başlamıştır. Zonaro'ya hem Mecidiye Nişanı hem de saray ressamlığı unvanını kazandıran resmi bu çalışmada incelenmiştir. Bu resim “Ertuğrul Süvari Alayı'nın Galata Köprüsü'nden geçişi” isimli eseridir (Şekil 14). Sanatçı Galata Köprüsü üzerinde, Ertuğrul Süvari Alayı'nın geçişini ilk gördüğü andan itibaren her Cuma Galata köprüsüne gelerek eskiz yaptığı bilinmektedir ve ayrıca, kompozisyon içerisinde bu sahneye tanık olarak kendisini ve eşini de resmetmiştir (Çötelioğlu, 2013: 106). İstanbul'daki yaşamı çok uzun sürmemiş, Padişah'ın tahtan indirilmesiyle birlikte Zonaro'nun da işine son verilmiş; evine ve eşyalarına da el konulmuştur. Bunun üzerine doğduğu şehre San Remo'ya dönen Zonaro, 1929 yılında ölene kadar İstanbul özlemiyle yaşamıştır (URL-18). 


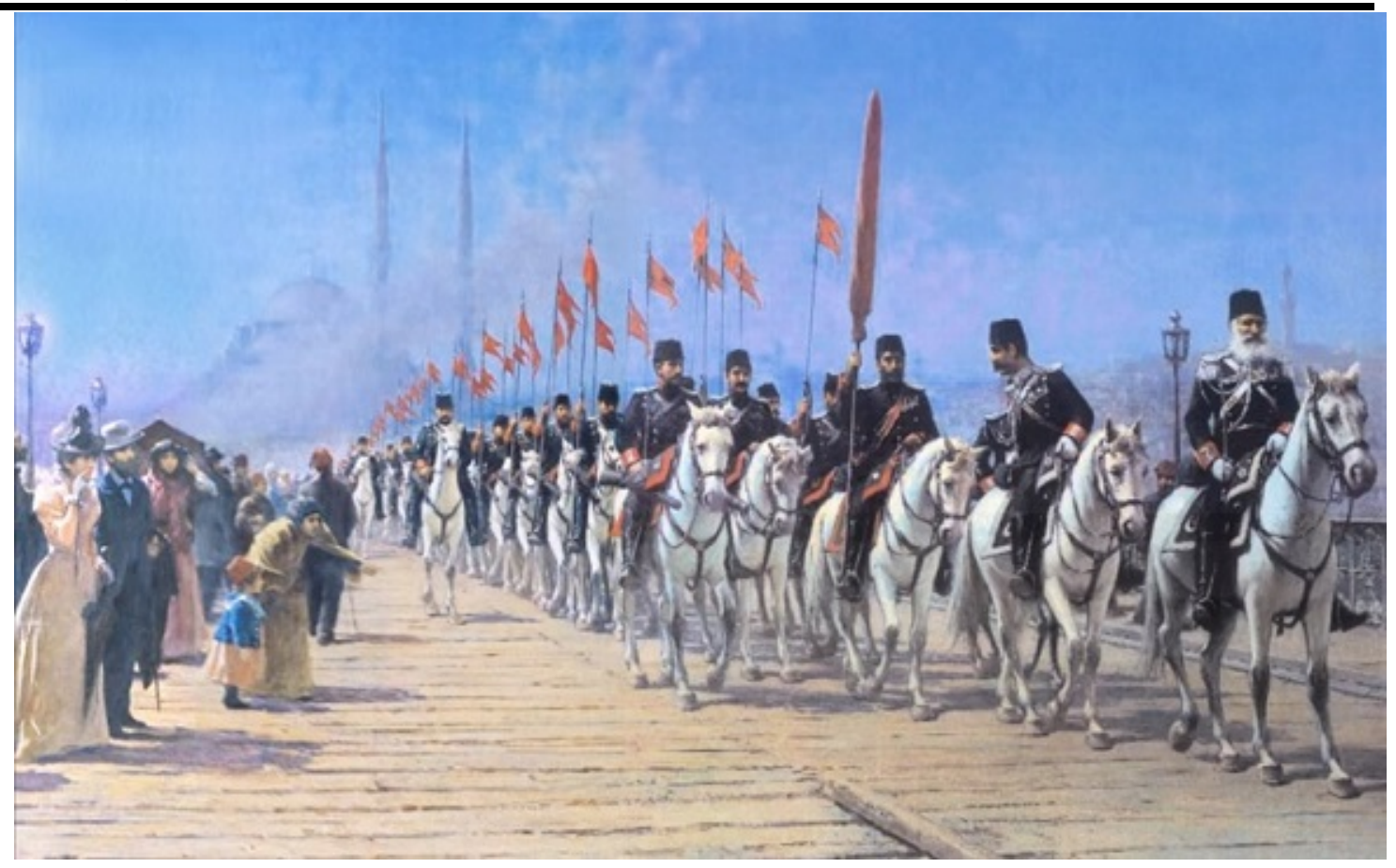

Şekil 14: “Ertuğrul Süvari Alayı'nın Galata Köprüsü’nden Geçisi” isimli tablo (1901) (Gürçağlar, 2000).

Şekil 15'de gördüğümüz Fausto Zonaro'nun yapmış olduğu Eminönü resmi Galata Köprüsü üzerinden Yeni Camii'ne doğru bir bakış açısıyla tasvir edilmiştir. İlk kalıcı köprü için girişimler II. Sultan Beyazıd tarafından, Leonardo da Vinci'den köprü tasarımı istemesiyle başlamış; fakat 1845 yılında Sultan Abdülmecid'in annesi Bezm-i Alem Valide Sultan'ın emriyle köprü yapılmıştır. Bu köprü 18 yıl kadar kalmış, 1861 yılında Sultan Abdülaziz'in emri üzerine yeniden inşa edilip; 1863 yılında yerine takılmıştır. İkinci köprünün de kalıcılığı çok uzun sürmemiş, 1872 yılında bir İngiliz firmasına inşası verilmiş, üçüncü Galata köprüsü 1875 yılında tamamlanmıştır. 480 metre uzunluğunda, 14 metre genişliğinde ve 24 duba üzerinde duran bu köprü 1912 yılına kadar kullanılmış ve bu tarihten sonra Haliç'in yukarılarına doğru çekilmiştir (Demirarslan, 2017:933) .

Fausto Zonaro, ailesiyle birlikte İstanbul'da yalnızca 14 yıl kadar yaşamış, üçüncü ve dördüncü Galata Köprüsü'nü görmüştür. Şekil 15' de Fausto Zonaro'nun Eminönü isimli kompozisyonunda görüldügü üzere Galata Köprüsü'nün zemini eğimli ve ahşap görünümlü yapılmıştır. Bu da bize bu köprünün zemininin ahşap olan üçüncü Galata Köprüsü olduğunu göstermektedir. Şekil 16 'da gördüğümüz üçüncü ve dördüncü Galata Köprüsü'ne ait Abdullah Biraderler, James Robertson ve Bergrenn'e ait fotoğraflarda da köprünün bağlandığı yer Yeni Camii'nin önüne denk gelmektedir ve bu fotoğraflardaki köprü ile karşılaştığında ise resimdeki köprünün üçüncü Galata Köprüsü olduğu açıkça görülmektedir. Günümüzde Galata Köprüsü'nün konumu 1992 yılında çıkan yangından sonra değişmiştir. Yerine beşinci Galata Köprüsü inşa edilmiştir ve bugün hala bu köprü kullanılmaktadır. 
Mimarlık ve Yaşam Dergisi Cilt: 2, No: 1, 2017 (121-151)

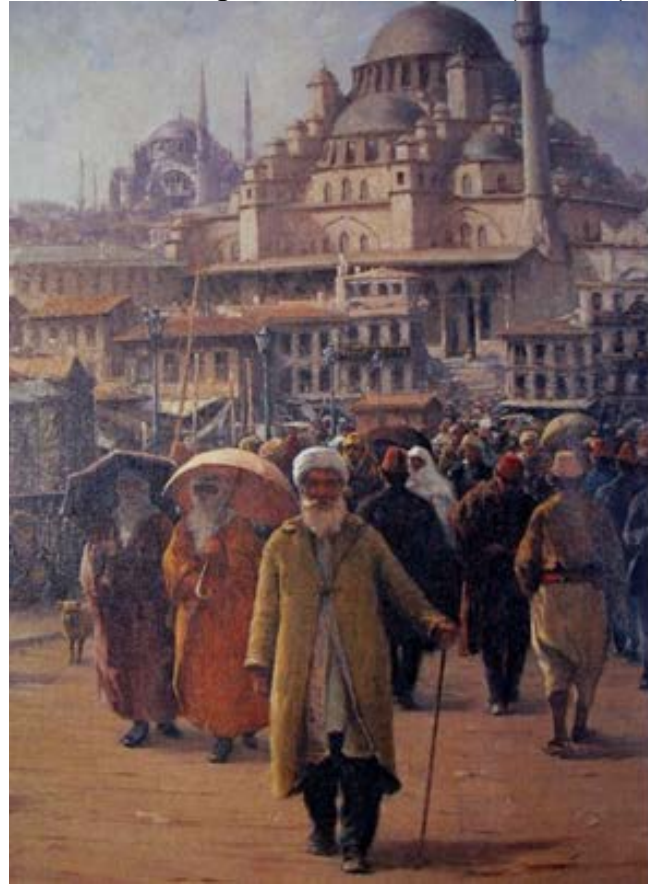

Deniz DEMIRARSLAN, Begüm SAVCIN

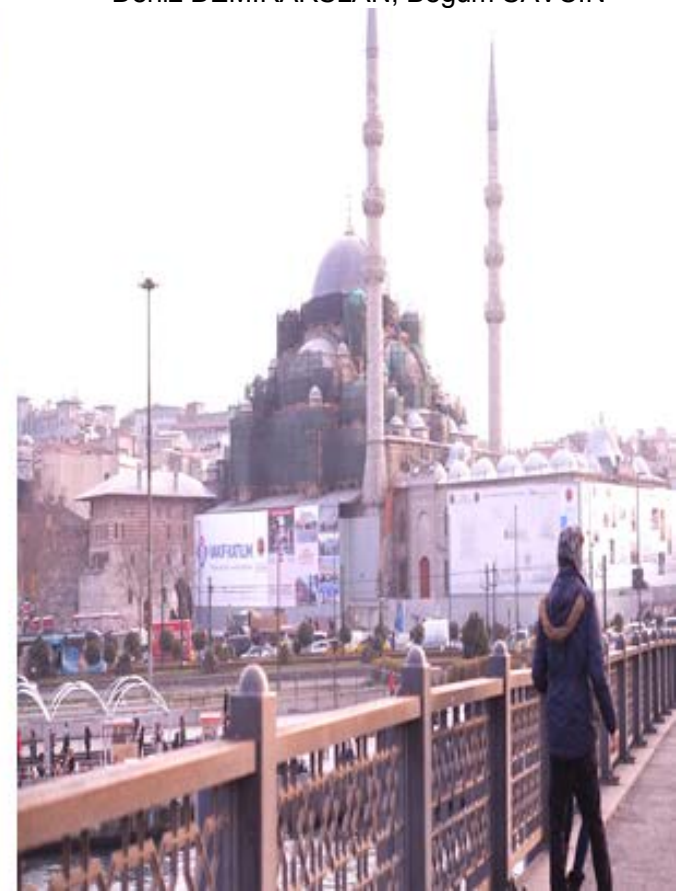

Şekil 15: Zonaro'nun tablosunda Galata Köprüsü (URL-19) ve (Foto.4: E.Begüm Savçın) Yeni Camii ile benzer bir açıdan mekânın günümüzdeki durumu.

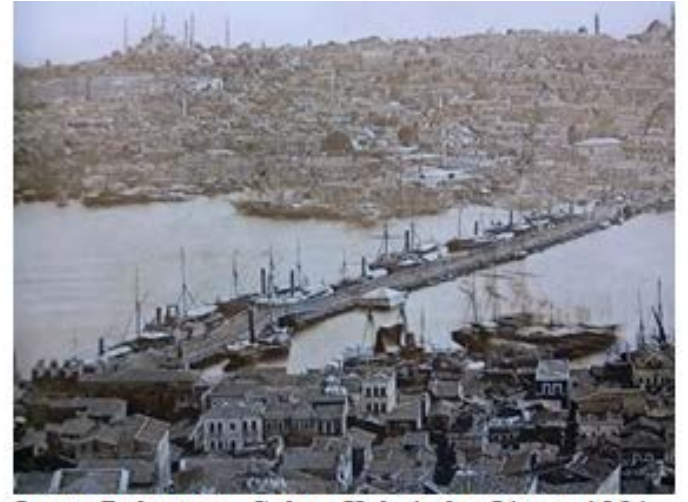

James Robertson- Galata Kulesinden Liman 1854.

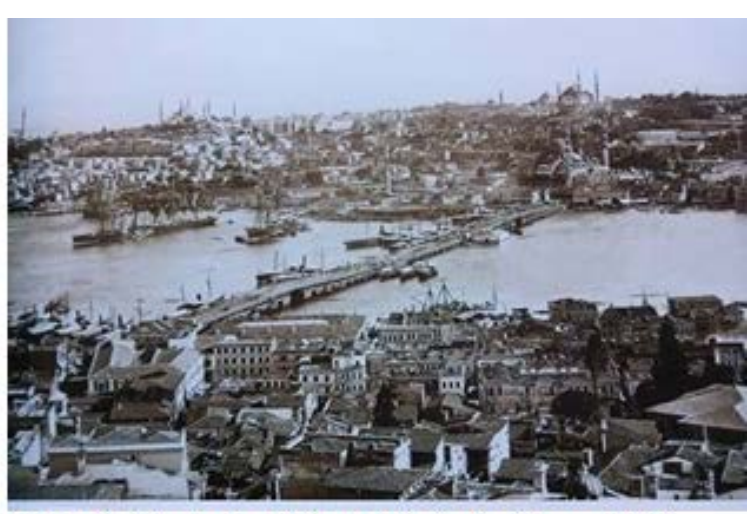

Abdullah Biraderler- Galata Kulesinden Liman 1868

Şekil 16: Robertson ve Abdullah Biraderler'in objektifinden Galata Köprüsü (Kıbrıs ve Ögel, 2000: 10-11)

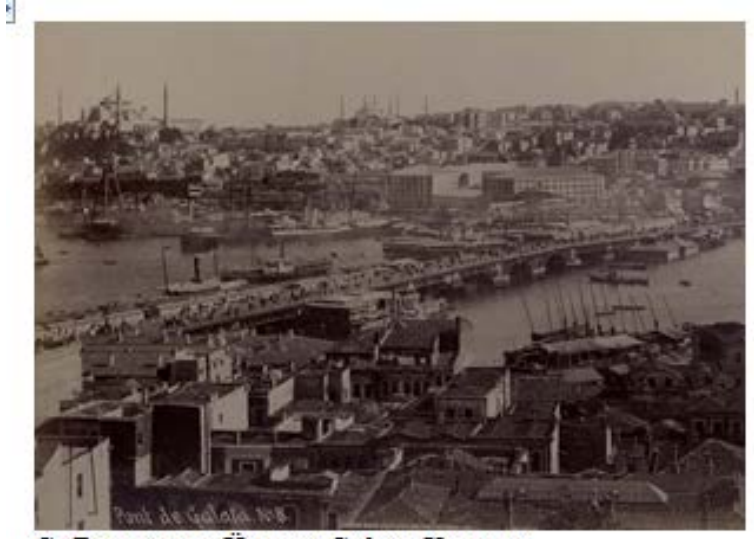

G. Berggrenn- Üçüncü Galata Köprüsü

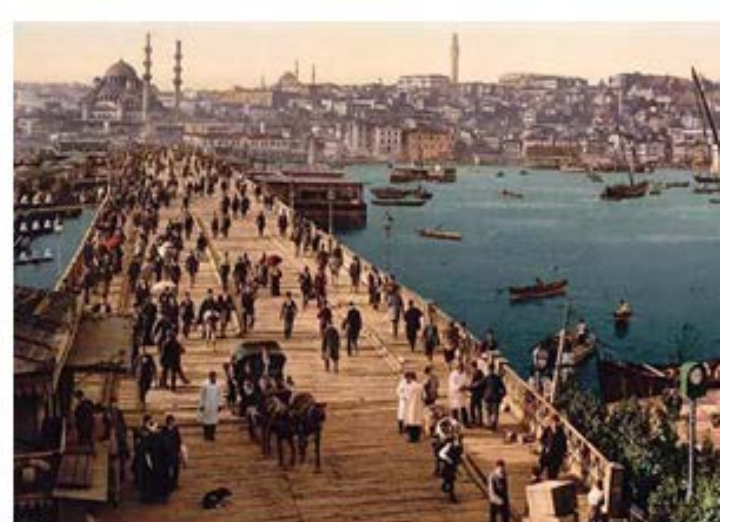

Üçüncü Galata Köprüsü- 1888

Şekil 17: 19. Yüzyılda fotoğraflarda belgelenen üçüncü Galata Köprüsü (URL-20, URL-21) 


\subsection{Francois Prieur Bardin'in eserinde İstanbul tasviri ve kentsel bellek}

Fransız ressam Bardin (1870- 1939), 1890-1901 yılları arasında İstanbul'da yaşamıştır. G.Berggren'in Üçüncü Galata Köprüsü isimli fotoğrafında Galata köprüsünün ayakları ile 1888 yılında fotoğrafı çekilen köprünün ortalarına doğru sağında ve solunda bulunan ahşap yapının, François Prieur Bardin'in resmettiği Eminönü resmiyle benzerlik gösterdiği görülmektedir. Ayrıca köprünün perspektifinin Eminönü'nde bulunan Yeni Cami'ye doğru oluşu da, ressamın gerçek manzara karşında bulunduğunun ispatı şeklindedir. Bugün çekilen fotoğrafta yeni Galata Köprüsü'nün açısı değişmiştir. Ressamın bakış açısıyla, fonda bulunan Beyazıt Kulesi kompozisyon içerisinde bulunacak şekilde kadraj alındığında ise, Galata Köprüsü görülmemektedir. Yeni Camii'nin arka sağ ve sol tarafında bulunan camii siluetleri de, Bardin'in kompozisyonunda olduğu gibi yerlerinde bulunmaktadır. Buradan da anlaşılacağı üzere Bardin'in resim çalışması gerçekçi bir çalışma olarak kentsel belleğe katkıda bulunmaktadır (Şekil 18).
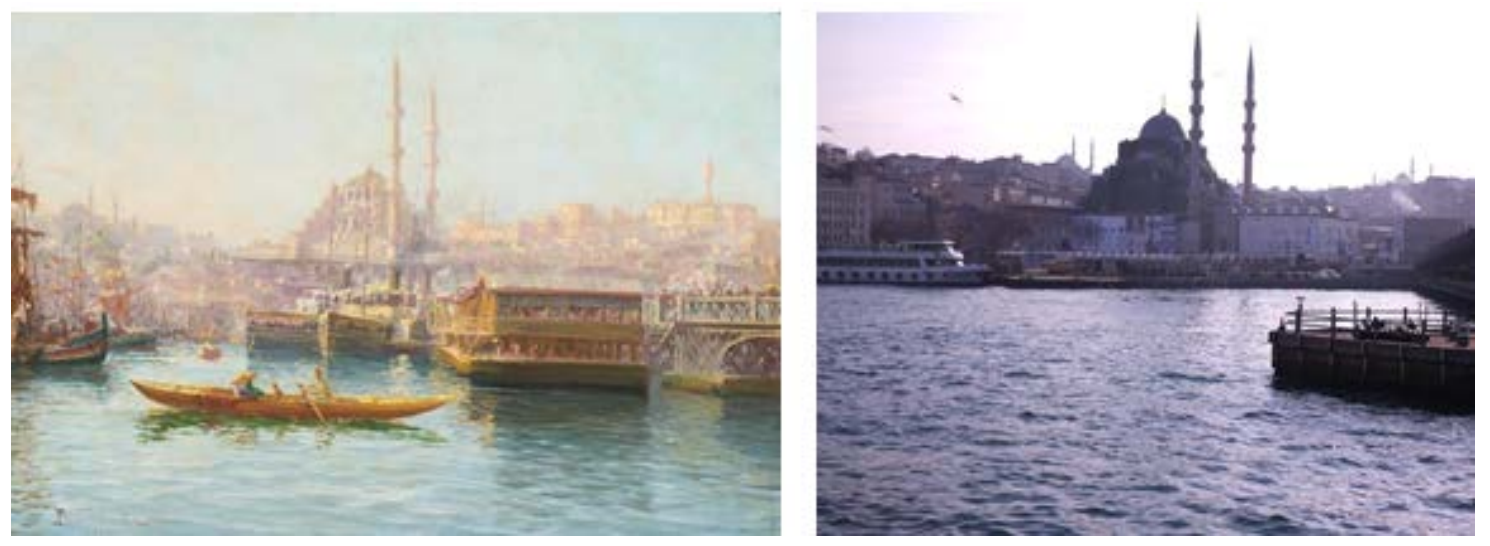

Şekil 18: Bardin'in tablosunda (URL-22) Eminönü ve (Foto.5: E.Begüm Savçın) Galata Köprüsü ile mekanın günümüzdeki durumu.

Bardin'in incelenen diğer resim örnekleri ise (Şekil 18 ve 19) bir limanı konu almaktadır. François Prieur Bardin'in İstanbul tarihi yarımadada bulunan bir limanı bir yıl arayla resmettiği iki resimdeki kompozisyon hemen hemen birbiriyle eş sayılacak bir benzerlik göstermektedir. Bunun sebebi ise sanatçının mekânın karşısına geçip çalışmış olma ihtimalidir. İkinci resim tarih olarak daha eski olup, solda bulunan vapur bacasından çıkan dumandan dolayı ya hareket edecek ya da limana yeni ulaşmış görünümündedir. 1899 yılında yapmış olduğu ilk resme konu olan mekân kuvvetle muhtemel bugün de hala liman olarak kullanılmakta olan Karaköy limanı, Tophane iskelesidir (Şekil 19, 20). Bu liman yalnızca yolcu gemilerinin yanaştığı bir liman olmamakla beraber aynı zamanda kayıkların karşı kıyıya yolcu taşıdıkları da bilinmektedir. Her iki resimde en önde olan Osmanlı kıyafetleri içerisindeki elinde bastonu beyaz sakalı ve sarıklı olan figürün ileri yaşlarda olduğu açıkça görülmektedir. Burada kayıkçı ile sohbet etmesi akıllara Jules Verne'in "İnatçı Kereban" romanını çağrıştırmaktadır. Romanda karşı kıyıya geçme vergisi arttırılınca sinirlenip, sırf daha fazla vergi ödememek için bütün Karadeniz'i dolaşan bir Türk tüccar anlatılır. Roman ilk kez 1883 yılında yayınlanmıştır. Bu resim roman yayınlandıktan 16 sene sonra resmedilmiştir. Fransız ressam bir başka Fransız yazar olan Jules Verne'in İnaçı Keraban isimli eserinden etkilenip Osmanlı topraklarına gelmiş olabilir. Ayrıca 1881 yılında Jules Verne'in de Osmanlı İmparatorluğu'nu ziyaret ettiği büyük olasılıktır. Kitapta bulunan mekân tasvirleri bugün de hemen hemen aynı mekânlardır. Ayrıca romanın en başında bahsedilen 16 Ağustos günü, Gömbeyaz.K. ' $n ı n$

\footnotetext{
${ }^{3}$ Gömbeyaz K. Yrd.Doç.Dr. Kocaeli Üniversitesi Illahiyat Fakültesi Öğretim Üyesi
} 
Mimarlık ve Yaşam Dergisi Cilt: 2, No: 1, 2017 (121-151)

Deniz DEMIRARSLAN, Begüm SAVCIN

vermiş olduğu hesaplama cetveline (URL-23) göre 1881 yılının Ramazan ayının yirminci gününe rastlamaktadır. Roman 1883 yılında yayınlandığına göre romanın yazılma tarihi 1881- 1882 yılları arasındadır. Yapılan araştırmalara göre (Özcan, 2008:5) 1881 yılında Jules Verne Hollanda, Danimarka ve Almanya'yı ziyaret etmiştir (URL-24). Ziyaretinin devamında Osmanlı topraklarında bulunduğu açıkça görülmektedir. Resimde dikkat çeken bir diğer unsur peyzaj içerisinde bulunan geminin aynısı, aşağıda o yıllarda Sebah ve Joailler tarafından çekilen fotoğrafta Galata limanında bulunmaktadır (Şekil 21) ( Kıbrıs ve Ögel, 2006: 14-15).

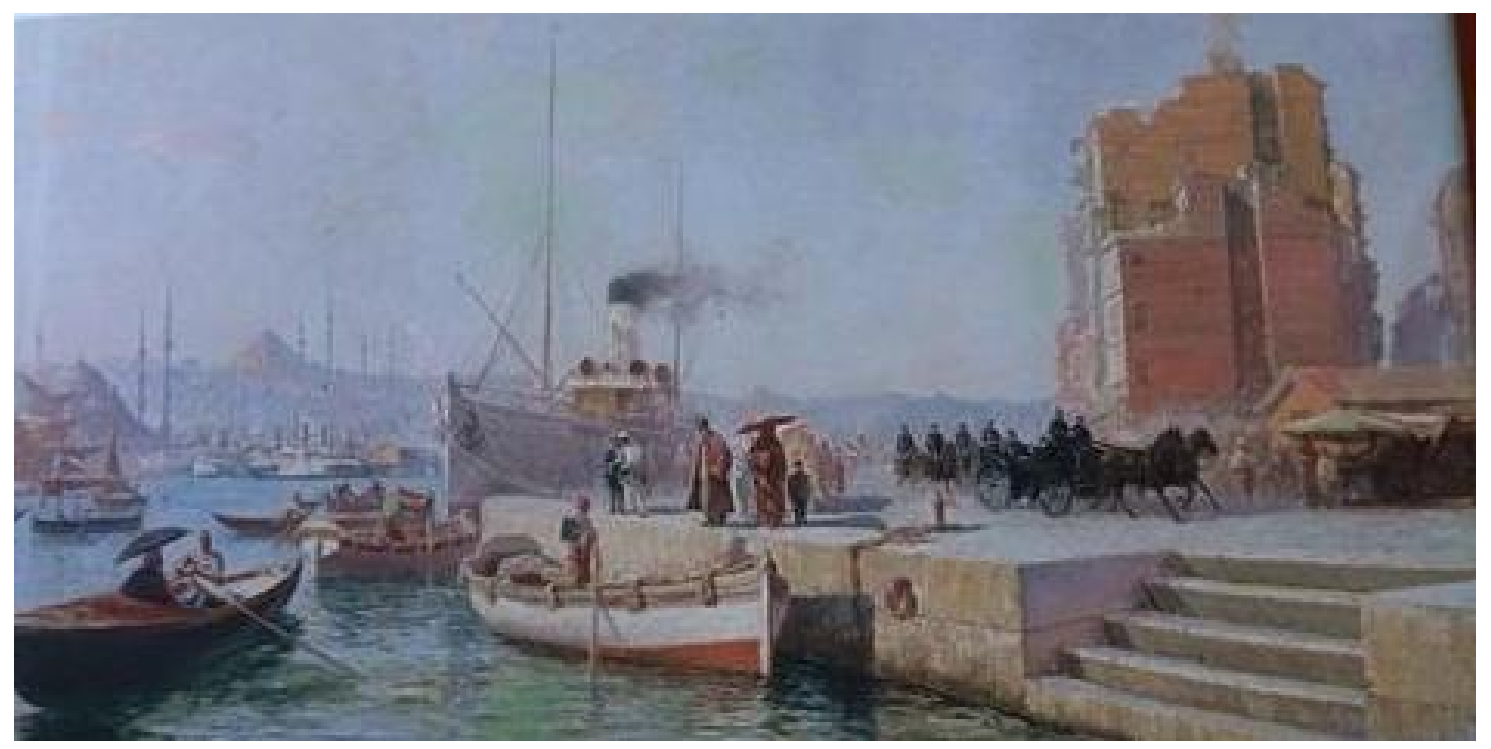

Şekil 19: François Bardin'in 1899 tarihli “Haliç'e Bakış” tablosu (Ustaoğlu, 2010: 75).

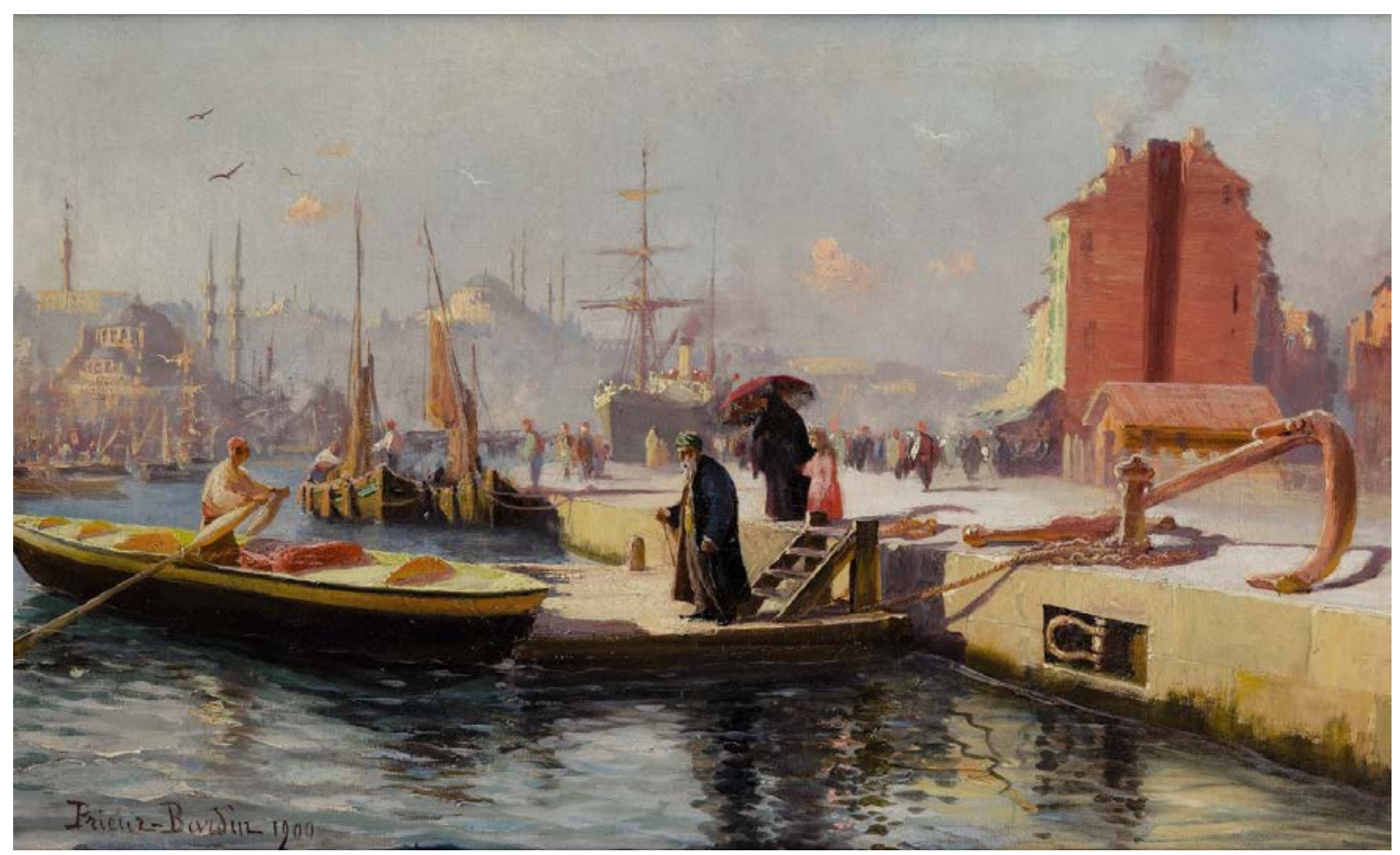

Şekil 20: François Bardin'in 1900 tarihli “Haliç'e Bakış” tablosu (URL-25). 

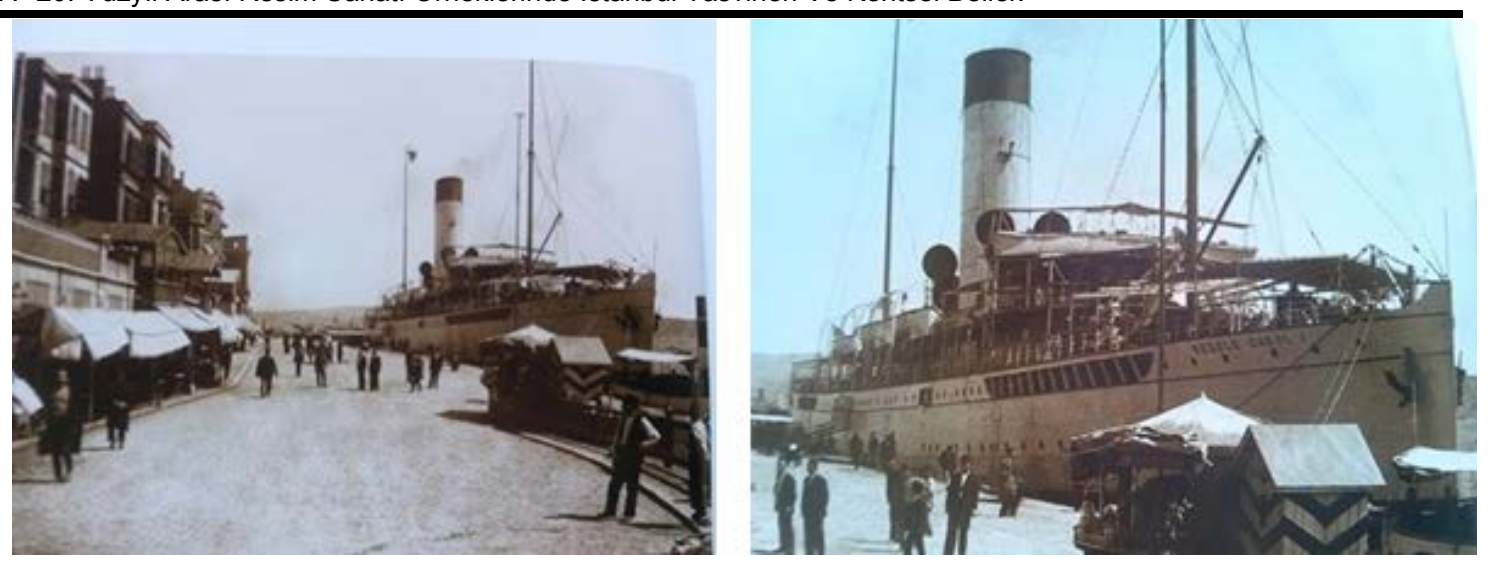

Şekil 21: Sébah\&Joaillier'in objektifinden Galata Rıhtımı-1900 (Kıbrıs ve Ögel, 2006: 14-15) (URL26).

Geminin ön tarafında yan yana bulunan batılı kıyafetler içerisinde olan iki figürün sağ tarafta beyaz kıyafetli erkek figürün elinde siyah bir kutu bulunmakta diğer koyu kıyafetli erkek figürü de o kutuya doğru bakmaktadır. Kutunun, George Eastman'ın 1888 yılında icat etmiş olduğu 'Kodak' ilk film kamerası olduğu intimali yüksektir (URL-27) (Şekil 22). Batılı iki erkeğin Marmara Denizi'ne doğru an'ın fotoğrafını çekerken, arkalarından bir devlet büyüğünün (1876-1909 yılları arasında Osmanlı İmparatorluğunun başında II.Abdülhamid bulunmaktaydı. Burada at arabasının içerisinde Galata rıhtımından büyük bir intimalle Dolmabahçe Sarayı'na doğru giden, askeri kıyafetler içerisinde beyaz sakalıyla ya padişahın kendisi ya da yüksek rütbeli bir askerin) tasviri yapılmıştır.
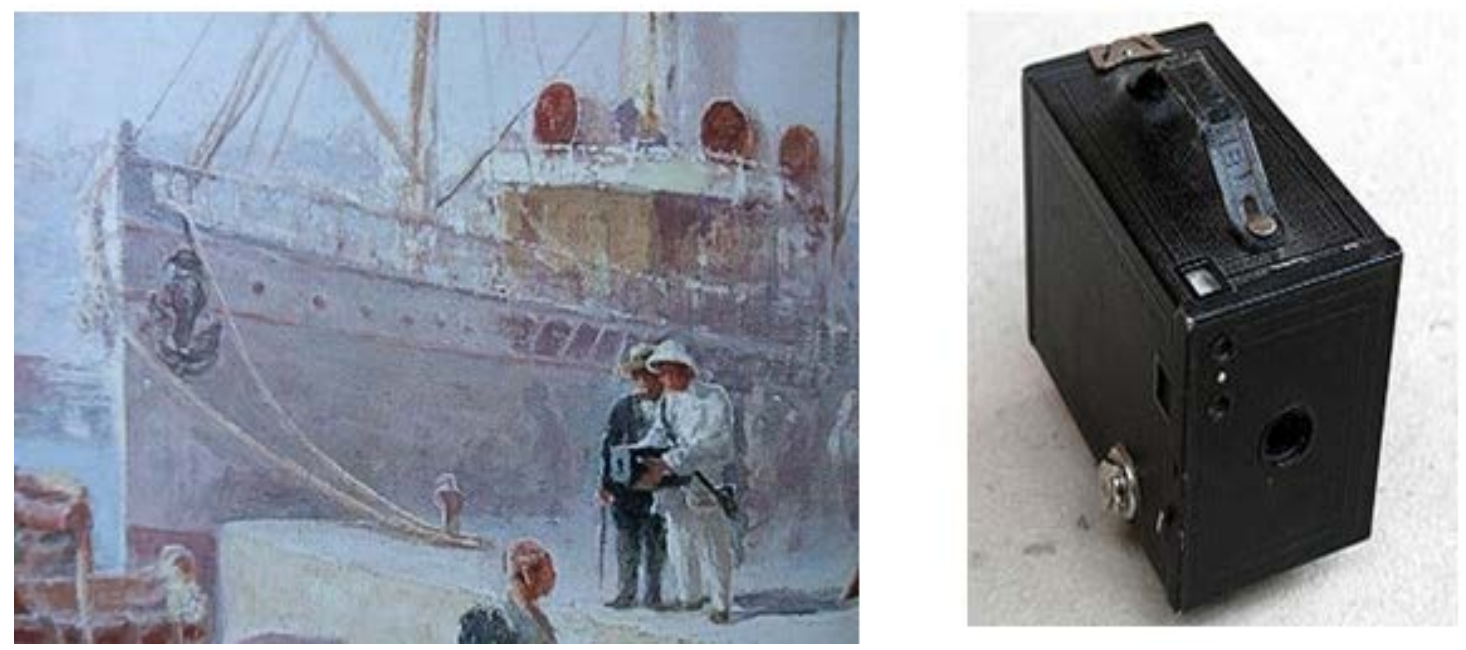

Şekil 22: Bardin'in tablosundan detay ve ilk "Kodak" fotoğraf makinesi URL-26a). 


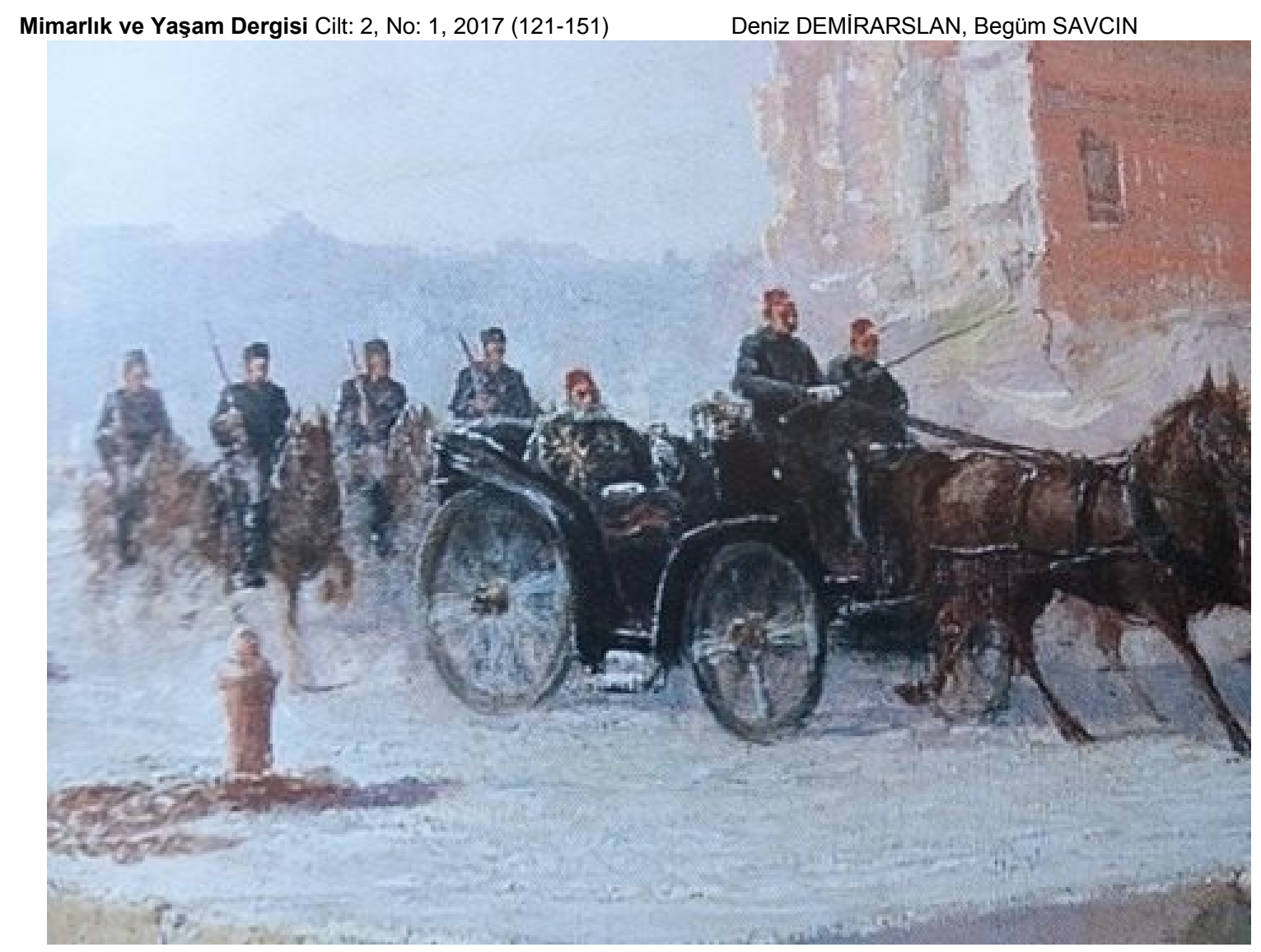

Şekil 23: Bardin'in tablosundan detay

Resimdeki detay incelendiğinde fotoğraf çekenlerin kıyafetleri de dönemin Batılı kıyafetleri ile örtüşmektedir. Fotoğrafı çekenlerin de gezgin, casus ya da o dönem Osmanlı ordusunda görevli İngiliz subaylar olması intimali yüksektir (Şekil 23, 24)(Gençoğlu, 2015: 606).

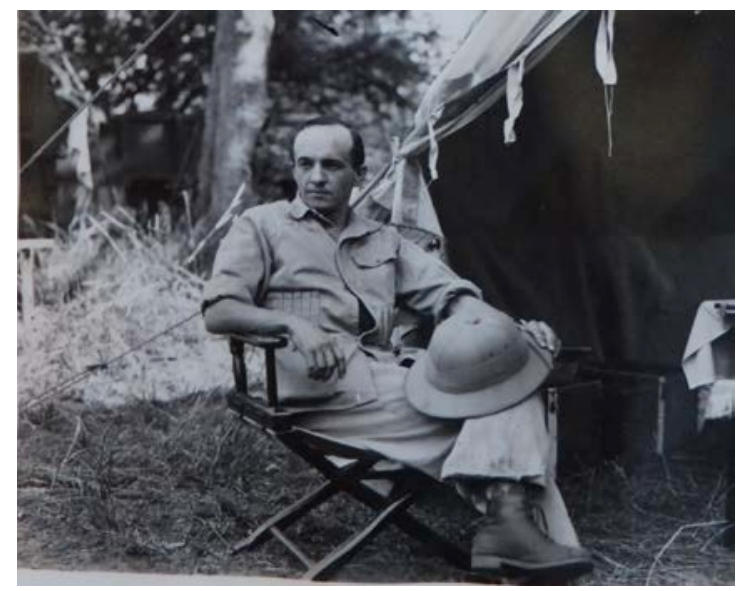

Şekil 24: Dönemin İngiliz kıyafetleri (URL-28).

Bardin'e ait incelenen bir başka resim ise Üsküdar'ı konu almaktadır. Bugün Üsküdar sahilinde Francois Prieur Bardin'in yapmış olduğu resmin açısından fotoğraf çektiğimizde, karşı yakada görülen tarihi Galata kulesi, Haliç, tarihi yarımada, Beyazıt kulesi, Nusretiye Camii, Ayasofya, Topkapı Sarayı olduğu gibi görülmektedir. Resimde görülen yalı bugün yerinde değildir. Onun yerine deniz doldurularak asfaltla yapılmış bir sahil yolu, birçok 
araba, minibüs, toplu taşıma aracı, tabelalar, otobüs durağı, ağaçlar, sanatçının resminden daha farklı bir kompozisyon oluşturmakta ve Üsküdar sahil şeridinin geçirmiş olduğu değişimi gözler önüne sermektedir (Şekil 25).
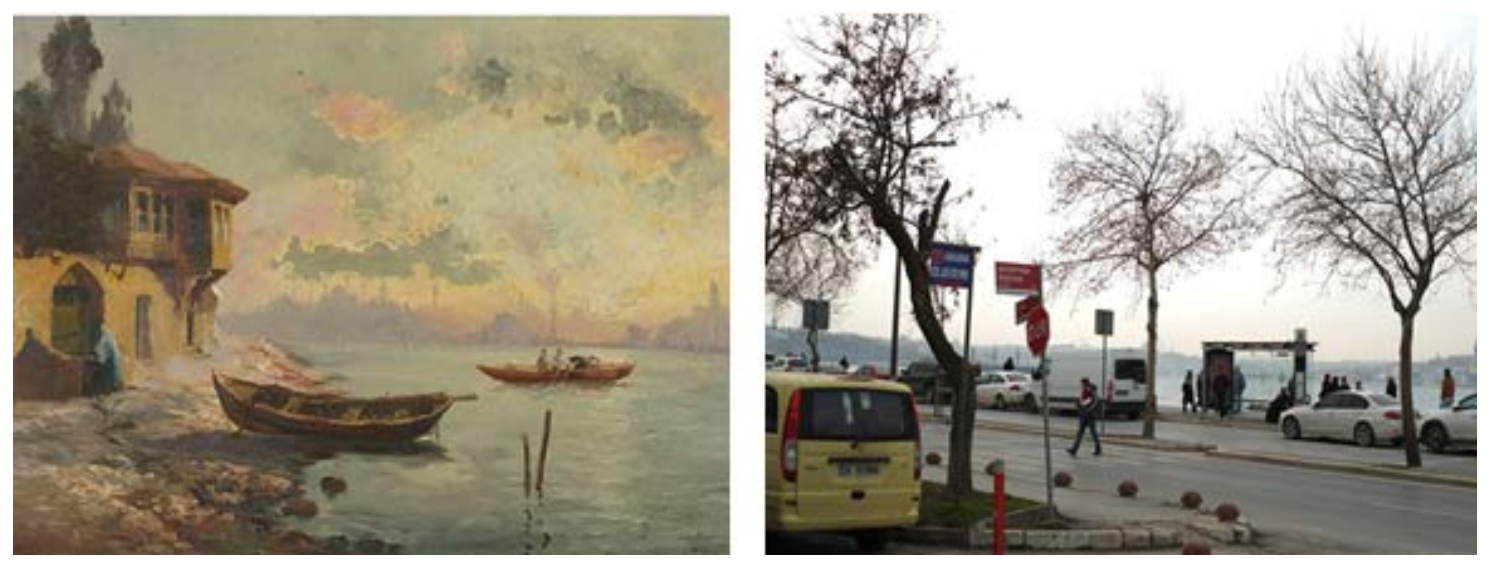

Şekil 25: Bardin'in Üsküdar'ı konu alan tablosu (URL-29) ve (Foto.6: E.Begüm Savçın) mekanın günümüzdeki durumu.

\section{20. YÜZYIL TÜRK RESMINDE ISTANBUL TEMASI VE KÜLTÜREL BELLEK}

İstanbul'un fethinden sonra Fatih Sultan Mehmed'in özellikle sanat çalışmaları için sarayın içerisine doğu ve batı atölyelerini açtırıp, doğu atölyesine minyatür ve hat ustalarını, batı atölyesine batılı ressamları eğitim vermeleri için davet ettiğini ve sonrasında burada eğitim verildiği bilinmektedir. Osmanlı dönemi boyunca üretilen eserler ağılıklı olarak minyatür, hat v.b geleneksel Türk sanatına aittir. Fakat batı atölyesine ait eserler ile ilgili bir bilgiye rastlanmamıştır. Geleneksel Türk el sanatlarından minyatür sanatında batı resim sanatında olduğu gibi İstanbul, sokakları, günlük yaşam sahneleri işlenmemiştir. İstanbul ve doğal güzellikleri, askeri zaferler, tören ve şenlikler günlük olayların arkasında bir fon olarak betimlenmiştir (Berk, 1977:9). 19. yüzyıl ortalarına 15 yıl kala Osmanlının batılılaşma süreci Türk resim sanatının başlangıcı olarak kabul görmektedir (Erden, 2012:6). Bu dönemde özellikle 1830'larda resim sanatına çalışmak üzere Avrupa'ya giden ilk Türk ressamlarına rastlanmaktadır. Ferik Tevfik Paşa 1835'de Viyana'ya, bir başka Tevfik Paşa Paris'e, Hüsnü Yusuf 1849'dan sonra Batı'nın çeşitli şehirlerine giderek yağlı boya tekniğini öğrenmeye çalışmışlardır.

Bu ressamlar istikrarlı bir şekilde teknik öğrenmişler ve bu tekniğin dışında bir uygulama yapmamışlardır. Fakat sonrasında yurt dışında eğitim görmüş ve vatana dönen Ahmet Ali, Hüseyin Zekai Paşa, Süleyman Seyit ve Osman Hamdi gibi ressamlar Türk resim sanatının bir kişiliğe oturmasında ilk örnekleri oluşturmuşlardır (Berk, 1977: 11). Özellikle, Osmanlı sadrazamlarından biri olan İbrahim Ethem Paşa'nın oğlu Osman Hamdi Bey, ilk Türk ressamlarından birisidir ve Türk resminde figürlü kompozisyon kullanan ilk ressam olarak tarihe geçmiştir. Günümüzde varlığını Mimar Sinan Üniversitesi Güzel Sanatlar Üniversitesi olarak sürdüren Sanayi-i Nefise Mekteb-i Alisi'nin de kurucusudur (URL- 30). Böylelikle sanat eğitimi 1883 yılında Osman Hamdi Bey'in çabalarıyla kurumsallaşmıştır. Yalnız Sanay-i Nefise değil aynı zamanda yeni açılan askeri liselerde verilen resim dersleri ile o dönemlerde ilk asker ressamlarının ortaya çıktığını görmekteyiz. Genel olarak Türk resim tarihine baktığımız zaman Asker Ressamlar, kendisini takip eden dönem içerisinde sivilleşmeye başlayarak, 1914 kuşağına ve sonrasında Cumhuriyetle birlikte yerini tamamen sivil sanatçı gruplarına bırakmıştır. "Osmanlı Ressamlar Cemiyeti" 1908'de kurulmuştur. Bu cemiyet, 1921'de “Türk Ressamlar Cemiyeti” olmuş; 1926'da 
Mimarlık ve Yaşam Dergisi Cilt: 2, No: 1, 2017 (121-151)

Deniz DEMIRARSLAN, Begüm SAVCIN

isim değiştirerek "Türk Sanayi-i-Nefise Birliği" haline gelmiştir. Sonunda, 1926'da, "Güzel Sanatlar Birliği"nde karar kılınmıştır (URL- 31). Kent ve kültürel bellek çalışması içerisinde asker ressamlarla birlikte, Müstakil Ressamlar ve Heykeltıraşlar Birliği, D grubu ressamlarının resimleri üzerinden zaman içerisinde mekânın nasıl değiştiğini kültürel bellek çalışması içerisinde inceleyeceğiz.

\subsection{Hoca Ali Rıza'nın eserinde İstanbul tasviri ve kentsel bellek}

İlk olarak, ressamlar tarafından İstanbul'un gelip geçenlerden uzak, sessiz yerlerini seçme 1914 dönemine kadar sürer. Bu dönemde, Şeker Ahmet, Hüseyin Zekayi Paşa, Süleyman Seyyit Bey, Osman Hamdi Bey ormanların kuytuluğunu, kıyıların tenhalığını, sokak içlerini, şehrin ıssız köşelerini ağırlıklı olarak resmetmişlerdir. Ancak dikkati çeken bir husus 20. yüzyıl Türk ressamları tarafından Üsküdar ağırlıklı olarak resmedilmiştir. Bu ressamların en önemlilerinden biri ressam hocası olarak anılan Hoca Ali Rıza (18641935)'dır. Kendisi de Üsküdar doğumlu olan ressam asker kökenli bir sanatçı olup; 1891 yılında Osmanlı Devleti'nin ilk başkentlerinde inceleme çalışmaları yapan bir heyete katılarak Türk-İslam eserlerine ait görünümleri defterlerine aktarmıştır. 1895'te Kolağası rütbesindeyken Yıldız Porselen Fabrikası'nda porselen tasarımları yaptı. Aynı yıl Fausto Zonaro'yla tanışmıştır. Karakalem ile suluboya tekniğindeki yetkinliği ve hızlı çalışma temposuyla, çok sayıda İstanbul peyzajı, kentin mahallerini, Üsküdar'dan Bebek'e, Arnavutköy'den Burgazada'ya kadar semt yaşantılarını, kahvehaneleri, deniz kıyılarını yorumlamıştır (Berk, 1977: 31-34).

Hoca Ali Rıza'nın 1914 kuşağı sanatçıları arasında bir köprü olarak değerlendirilebilen ve ressamın sanat anlayışını yansıtan en belirgin tablosu (Erden, 2012: 34) olan "Fenerli Sokak tablosu incelendiğinde (Şekil 26); Arnavut kaldırımlı bir sokakta ahşap kaplamalı, cumbalı cepheleri ile 19. yüzyıl-20.yüzyıl başına ait geleneksel Türk evleri görülmektedir. Berk eserinde Üsküdarlı Hoca Ali Rıza'yı şöyle anlatmaktadır (Berk, 1977: 20):

"Hoca Ali Rıza'nın anılması birden, kişinin gözleri önünde, çizgilerini, biçim ve renklerini hatırlamakta güçlük çekmeyeceği bir tablo dizisi sıralar: Aşı boyalı ahşap evler, neredeyse birbirine yaslanacak cumbalar, Arnavut kaldıımlı sokaklar, mezarlıklar, serviler, çeşmeler, öğle güneşinin kavurduğu, aralarından ot fışkıran beyaz, sarı, esmer renkte kayalıklar, çayırlar, ağaç kümeleri, kır kahveleri."

Berk eserinde şöyle devam etmektedir:

“... hoca'nın yaşamı sırasında Üsküdar 19. Yüzyıl görüntülerinden sıyrılmamıştı... Sokakları, evleri, çınarları ve servileriyle eski İstanbul'un son kalıntısıydı Üsküdar."

Resme adını veren sokak aydınlatması- fener resmin odak noktasıdır. Sokak aydınlatması olması bu sokağın sosyal ve ekonomik düzeyi yüksek kesimin oturduğu bir sokak olduğunu düşündürmektedir (URL-32). Üsküdar'da benzer sokaklar incelenmiş ve günümüzde bitişik nizamda betonarme apartman yapılarının çoğunlukta olduğu Üsküdar sokaklarında tek tük kalmış ve resimdekine benzer ahşap konut örneklerinin restore edilerek koruma altına alınmış olduğu görülmektedir. Fotoğraftaki konutun yan cephesinde yer alan pencereler ile resimdeki konutların giyotin pencereleri, ahşap cephe kaplamaları, çatı saçakları, eli böğründeler, konutların bahçe- sokak ilişkileri aynıdır. Ne yazık ki; fenerli sokak aydınlatmaları günümüzde yoktur. Günümüz konutlarının çatılarında uydu antenler, ahşap bahçe çitlerinin yerini ise garaj kapıları almıştır. Arnavut kaldırımlı eski İstanbul sokağında günümüzde sokak aydınlatması yerine yerdeki çöp torbaları dikkati çekmektedir. Hoca Ali Rıza'nın tasvirinde gerçekçilik göze çarpmaktadır. 

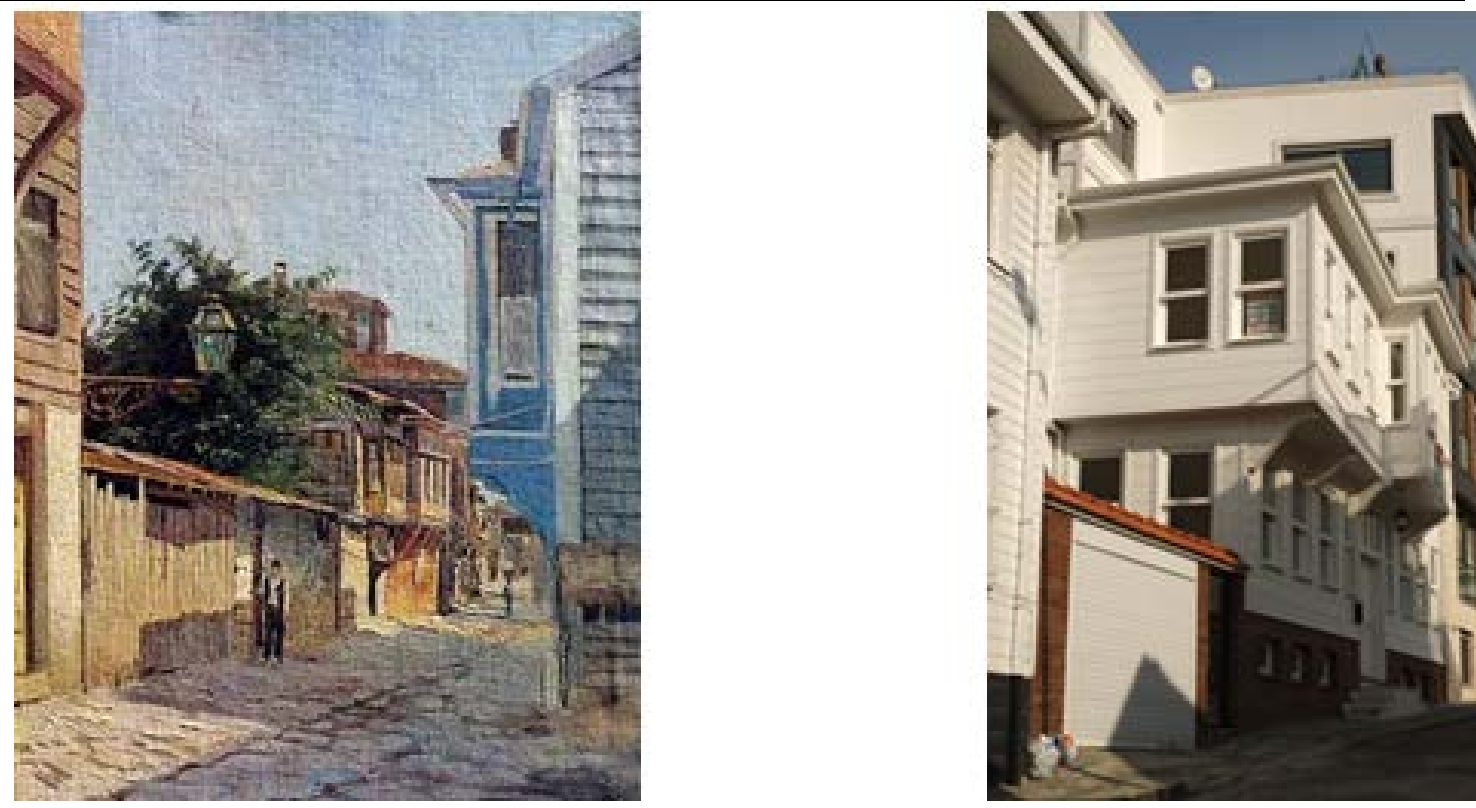

Şekil 26: Hoca Ali Rıza'nın “Fenerli Sokak" resmi (Berk, 1977) ve (Foto.7: S.Burak Savçın) günümüzdeki durumu.

\subsection{Ahmet Ziya Akbulut'un eserinde İstanbul tasviri ve kentsel bellek}

Ressam Ahmet Ziya Akbulut (1869- 1938) sanata olduğu kadar, matematik ve astronomiye de meraklıydı. Takvim-i Ziyayı o tertip etmiş ve yayınlamıştır. Aynı zamanda menazırcı (perspektifçi) olarak da ünlendi. Eserleri de bunu ortaya koymaktadır. Ahmet Ziya 1937 yılında İstanbul Resim ve Heykel Müzesi açılıncaya ve Atatürk'ün emriyle her ressam oraya birer ikişer eser bağışı yapıncaya kadar keşfedilmeyen bir sanatçı olarak kaldı. Herkesin gözünde o, bir ressamdan çok bir perspektif hocasıydı (URL-33).

Ahmet Ziya Akbulut'un "Üsküdar Meydanı" isimli tablosu incelendiğinde günümüzdeki durumu ile birebir olduğu görülmekle beraber yol- kaldırım ilişkisi ve fondaki binaların değişimi gözlenmiştir. Perspektife önem veren bir ressam oluşu resminde gerçekçi bir yaklaşım da getirmiştir. Aynı dönem aynı açıdan çekilmiş fotoğraf da bize Akbulut'un gerçekçi bir çalışma sunduğunu ispatlamaktadır (URL-34) Günümüzde yeşil doku azalmış ve Akbulut'un resminde III. Ahmed Çeşmesi ve Üsküdar Mihrimah Sultan Camii yer alırken, günümüzde aynı mekanda otomobiller ve trafik göze çarpmaktadır (Şekil 27) . 

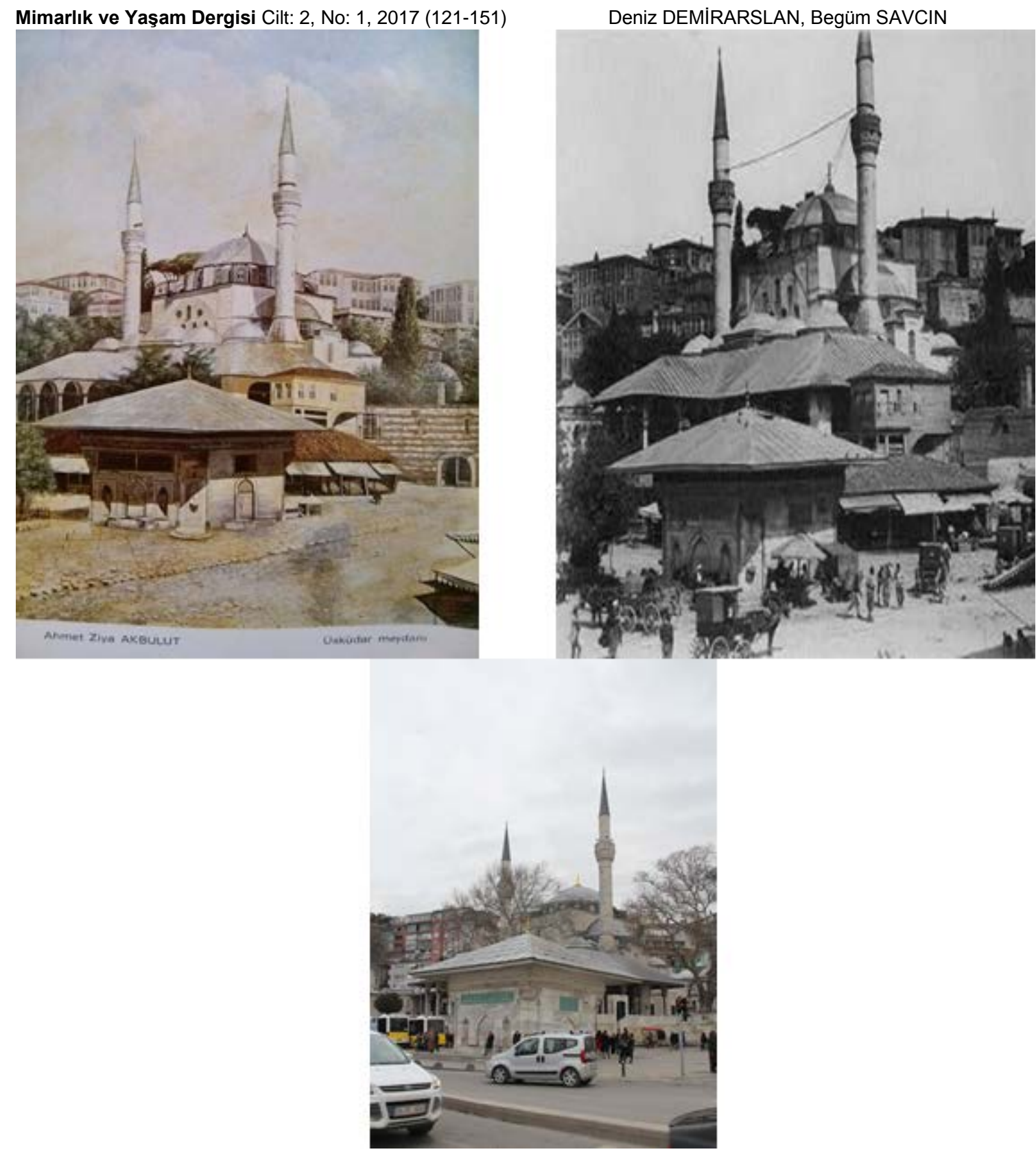

Şekil 27: Ahmet Ziya Akbulut'un “Üsküdar Meydanı” resmi ( Berk, 1977) aynı dönemde çekilmiş fotoğrafı (Berberoğlu, 2011: 117) ve (Foto.8: S.Burak Savçın) mekanın günümüzdeki durumu .

\section{3. İbrahim Çalı'nın eserinde İstanbul tasviri ve kentsel bellek}

Türk resim sanatının önemli ustalarından biri olan Çallı ( 1882- 1960) 1910 yılında Sanayii Nefise Mektebi'nden mezun olarak Paris'e gitmiştir. Valeri, Zarzecki ve Cormon'un öğrencisi olmuş ve Türkiye'ye döndükten sonra "Çallı Kuşağı" olarak da isimlendirilen 1914 Kuşağı sanatçılarıyla Şişli Atölyesi'nde savaş temalı resimler yapmıştır. Sanatçının peyzaj, natürmort, portre ve nü çalışmaları bulunmaktadır. Üslubu itibariyle Adnan Turani'ye göre akademikleşmiş bir izlenimci, Nusret İslimyeli'ye göre anlatımcı, Halil Dikmen'e göre izlenimci bir renk ustasıdır (Çötelioğlu, 2013: 1278). Kentin çeşitli yerlerinden yaptığı peyzajlarında; geniş fırça vuruşları ve devingen bir ışıkla aydınlanan renk yorumuyla sanatının tüm ustalığını ortaya koymuştur. 
İbrahim Çallı'nın " Üsküdar " isimli tablosu incelendiğinde; resimde Üsküdar Mihrimah Sultan Camii ile III. Ahmed Çeşmesi denizden resmedilmiştir. III.Ahmed Çeşmesi'nin tabloda çatı ve saçaklarının günümüzdeki halinden farklı olduğu tespit edilmiştir. XIX. yüzyıla ait gravürlerde, Üsküdar III. Ahmet Çeşmesi çatısının ortasının bir fener gibi yüksek olduğu görülür. Sonraları bu iki kademeli çatı bozularak, şimdi görülen çatı yapılmıştır. Saçak kenarları da, önceleri işlemeli iken daha sonra düz bırakılmıştır. Çeşme 1932'de bir tamir görmüş, 1943-1945'te meydanın düzenlenmesi sırasında çukurda kaldığından, 1955 'te Sular İdaresi tarafından bütün dış kaplamalar sökülmüş ve iç kâgir duvarları $150 \mathrm{~cm}$. yükseltildikten sonra, cephe unsurları yeniden yapıştırılmıştır. Ahşap çatı da hiç değiş̧irilmeden olduğu gibi yukarı kaldırılmıştır. 1987 yılındaki restorasyonda çeşmenin cephelerinde temizlik yapılarak, saçak altlarına yeni nakışlar işlenmiştir. Yapı son olarak 1999-2000 yıllarında bir restorasyon geçirmiştir. Dolayısıyla İbrahim Çallı da tablosunda gerçekçi yaklaşım ile Üsküdar meydanını denizden resmetmiştir. Ancak, Mihrimah Sultan Camii'nin gerek minare gerek pencereleri ile ön cephede yer alan saçaklarında görülen gerçeğe uymayan oran bozuklukları ise büyük bir olasılıkla kayıkta hızıı bir eskiz almasından kaynaklanmaktadır. Günümüzde ise denizin doldurulması ile yol deniz ile cami arasında kesinti oluşturmaktadır. Aynı zamanda kayık iskelesi yerine büyük bir vapur ve deniz otobüsü iskelesi bulunmaktadır (Şekil 28) (Sav ve Kuşüzümü, 2010: 4353).

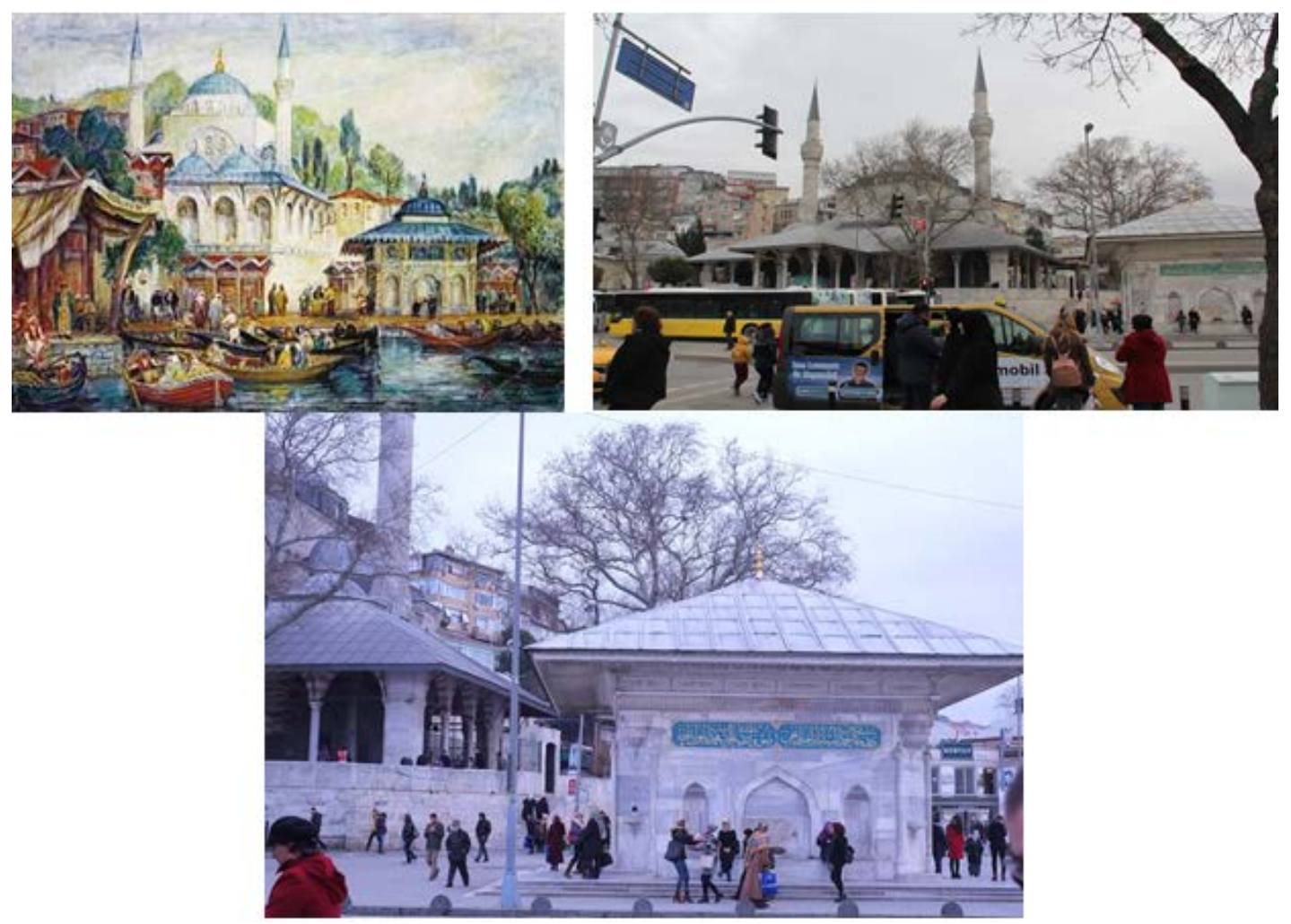

Şekil 28: İbrahim Çallı'nın eserinde (URL-35) ve (Foto.9-10: S.Burak Savçın) günümüzde Mihrimah Sultan Camii ile III. Ahmed Çeşmesi.

\subsection{Hikmet Onat'ın eserinde İstanbul tasviri ve kentsel bellek}

Türk resim sanatında 1914 Kuşağı temsilcilerinden bir olan Hikmet Onat ( 1882-1977) asker ressamdır. Osman Hamdi Bey, Valeri ve Cormon'un öğrencisi olmuştur. Osmanlı Ressamlar Cemiyeti ve Güzel sanatlar Birliği'nin kurucularındandır. Gerçek bir İstanbul tutkunu olan sanatçı, kentin çeşitli yerlerinden, özellikle de Boğaziçi kıyılarından izlenimci 
Mimarlık ve Yaşam Dergisi Cilt: 2, No: 1, 2017 (121-151)

Deniz DEMIRARSLAN, Begüm SAVCIN

bir tutumla betimlediği İstanbul manzaraları ile tanınmıştır. Sanatçını bir dizi çalışması da, Topkapı Sarayı'nın çeşitli mekânlarından yaptığı resimlerdir. Sarayın kapalı bölümlerine özel izinle girerek birçok odayı, belgeci bir tutumla betimlemiştir (Çötelioğlu, 2013: 126). Onat, resimlerini yerinde çizmekteydi. Bu konuyla ilgili olarak anılarında;

“...Hafif bir kahvaltıdan sonra kutumu, portatif şövalemi alır, Taksim Meydanı'na yollanırım. Sabah beşte Boğaz'a otobüs vardır. Ona biner istediğim yere giderim. Örneğin; bu yıl Sarıyer'e dadandım. Orada bir kıyı kahvesi var, kahveciyle ahbap olduk. Sabah çalıştıktan sonra tuvalimi, şövalemi ona bırakırım. Konuyu bir haftada bitiririm doğa karşısında. Resimlerime dışarıda başlar, dışarıda bitiririm. Eve dönünce onlara dokunmam genellikle." ( Berk, 1977: 29).

Buradan da anlaşılacağı üzere Onat resimlerinde gerçekçi bir tutum izlemiş; olanı belgelemiştir.

Hikmet Onat'ın en önemli özellikleri açık havada çalışmayı benimseyerek manzara resimleri yapmış olmasıdır. Hikmet Onat'ın "Üsküdar" isimli tablosu incelendiğinde Üsküdar'ı konu aldığı görülmektedir. Günümüzde tabloda yer alan bina artık yerinde yoktur. Sahil doldurularak yol geçirilmiş, metro istasyonu ve üst geçit yapılmıştır. Denizdeki ahşap kayıklar artık yoktur. Günümüzde aynı mekânda büyük bir insan ve araç trafiği göze çarpmaktadır. Dolayısıyla bu durum da Üsküdar'ın günümüzde bir merkez olduğunun kanıtıdır. Resmin sol üst köşesinde fonda görülen 1865 yılında hizmete açılan Kuzguncuk Gazhanesi'nin bacası da artık günümüzde yoktur. Günümüzde çekilen fotoğrafta kadraja girmiş olan ve elindeki telefona bakan sırtı denize dönük insan figürü de toplumsal bellek açısından önemli bir saptamadır (Şekil 29).
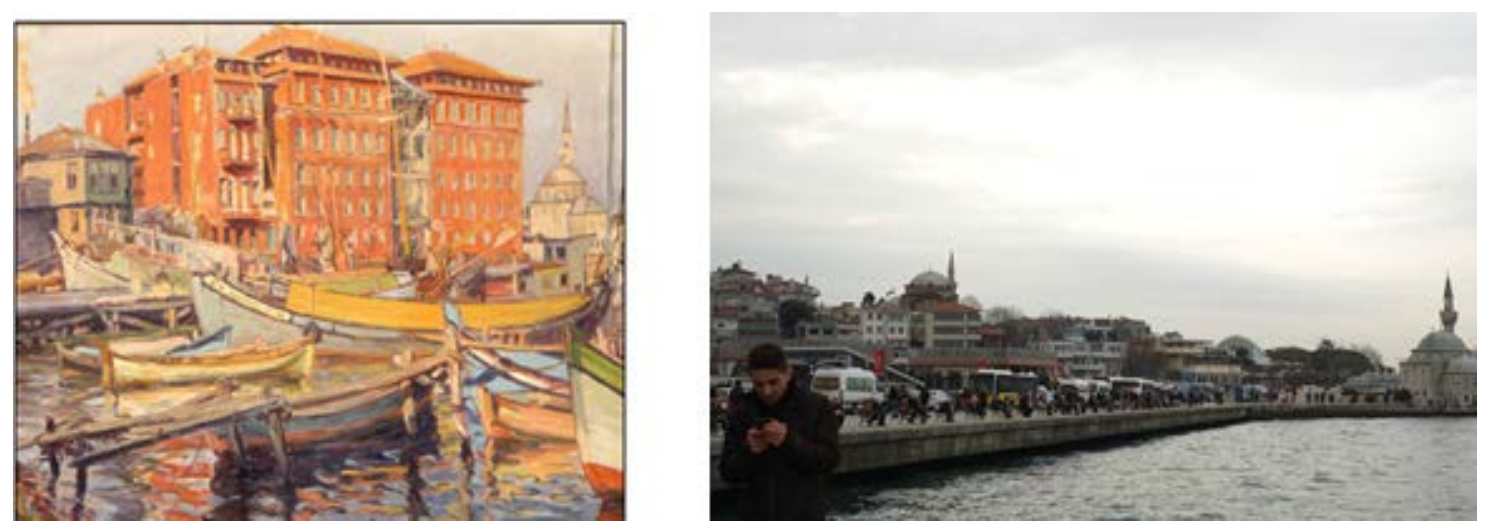

Şekil 29: Hikmet Onat'ın "Üsküdar" isimli tablosu (URL-36) ve (Foto.11: S.Burak Savçın) mekânın günümüzdeki durumu.

Onat'ın "Salacak'ta kayıklar ve Kızkulesi” isimli eseri incelendiğinde; denizde kayıklar ön plana çıkmaktadır. Onat öylesine sever ki yelkenlileri, kayıkları, yukarıdan bir açıyla bakar onlara resimlerinde, tüm ayrıntılarını resmedebilmek için. Dolayısıyla sadece manzara değil; dönemin ulaşım koşulları ve teknolojisi için de bir belge teşkil eder ressamın resimleri. Tekneleri süsleyen şeritler, renkler, motifler, halatlar, yelkenler öyle ayrıntılı bir şekilde resmedilmiştir ki Berk eserinde (1977: 29) bu resimlerden "yelkenli anatomisi" olarak bahsetmektedir. Resme adını veren Kızkulesi ile Salacak sahilinin değişimi açıkça görülmektedir. Önceden denizle iç içe, denize ulaşabilen bir Salacak halkı varken, günümüzde doldurulmuş kıyıda büyük beton bloklarının üzerinde zorlukla ayakta durabilen ve sırtlarını Boğaz'a dönmüş özçekim yapan insanlar dikkati çekmektedir. Artık 
insanlar, bozulan kent mekânlarının da etkisiyle denize sırtlarını dönmektedir. Karşı yakanın da silueti oldukça değişmiştir (Şekil 30).
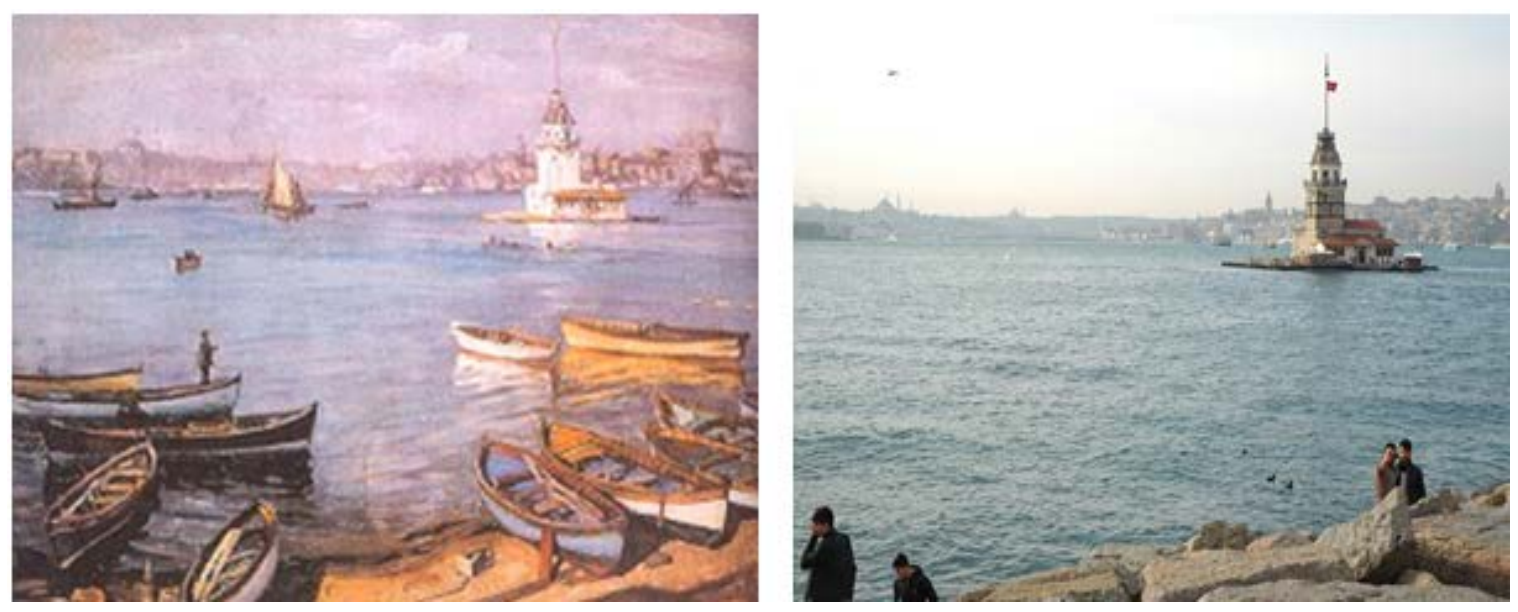

Şekil 30: Hikmet Onat'ın “ Salacak'ta kayıklar ve Kız Kulesi” isimli tablosu (URL- 37) ve (Foto.12: E.Begüm Savçın) mekânın aynı açıdan günümüzdeki durumu.

\subsection{Nazlı Ecevit'in eserinde İstanbul tasviri ve kentsel bellek}

Aydın bir ailenin kızı olan Nazlı Ecevit ( 1900- 1985) Feyhaman Duran'ın öğrencisi olmuş ve eşinin ölümünden sonra Üsküdar Salacak'ta yaşamıştır. Portre ve natürmort çalışmaları da bulunmakla birlikte resimlerinin birçoğunu Salacak ve Üsküdar'dan yaptığı peyzajlar oluşturmaktadır. Salacak'tan Kızkulesi ve İstanbul, Üsküdar'dan Karacaahmet, Şemsi Paşa görünümleri, anlık izlenimlerle resmedilmiş empresyonist resimlerdir (Çötelioğlu, 2013: 140).

Nazlı Ecevit'in "Salacak ve Kızkulesi" tablosu incelendiğinde resme konu olan evin günümüzde halen bulunduğu yerinde tespit edilmiştir. Nazlı Ecevit'in resmi çizerken yan arsadan açı alarak baktığı ancak günümüzde aynı yerde bir apartman yer aldığı görülmektedir. Dolayısıyla Üsküdar sırtlarının o yıllarda yeşilliklerle dolu iken; günümüzde betonlaştığının kanıtıdır. Kız Kulesi'inden Boğaz'a doğru bakışta ise Avrupa Yakası'nın siluetinin ve Boğaz'daki deniz taşıtlarının ne derece değiştiği görülmektedir (Şekil 31). 


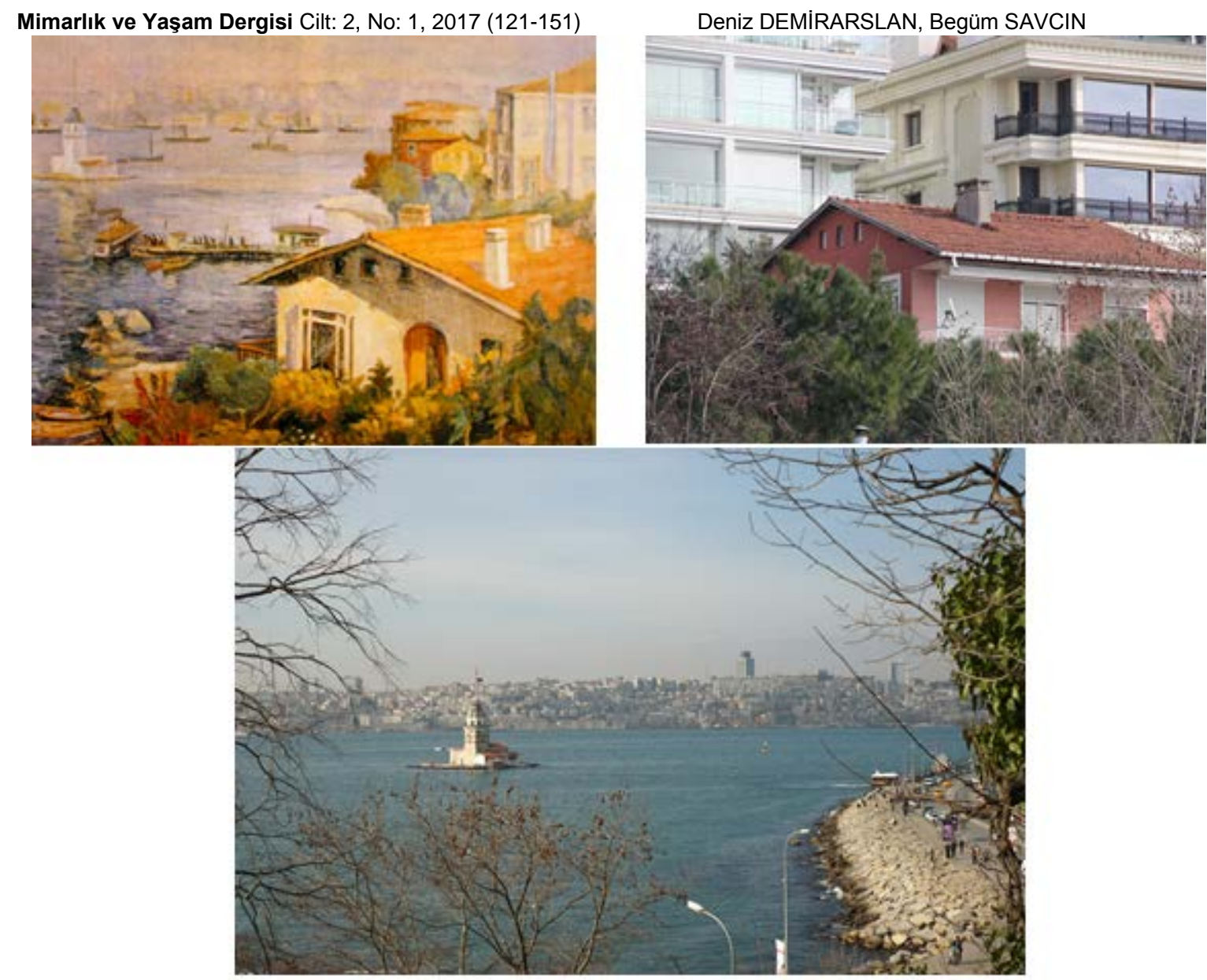

Şekil 31: Nazlı Ecevit'in "Salacak ve Kız Kulesi resmi (URL-38) ve (Foto.13-14: S.Burak Savçın) resme konu olan ev ve manzaranın günümüzdeki durumu

\section{DEĞERLENDIRME VE SONUÇ}

Nurullah Berk eserinde (1977: 37) kentlerin gelişimi ve değişimi hakkında şöyle söylemiştir:

"Avrupa'da öyle şehirler var ki, yüzyıllar öncesi çehrelerinden ya hiçbir şey, ya da pek az şey kaybetmişlerdir. Amsterdam, Roma, Venedik, Prag, Floransa; Avignon, Bruges bunlardandır. Geçmiş dönemlerin özlemiyle bu şehirleri gezen kişi, son yüzyılların katkısını kolayca unutarak, ayakta duran anıtları, evleri, eski sokakları, tüm olarak genel görünüşleri bir 17. Ya da 18. Yüzyıl adamıymış gibi doya doya seyredebilir, eski yaşamın dirilişini içinde duyabilir. Fransa ve Almanya'da öyle şehirler vardır ki, Ortaçağ'dan kalma mahalleleri, tahta evlerini kıskançlıkla korumuş, yaşatmışlardır. Guardi'nin Canaletto'nun Venediği ile bugünkü arasında bir fark, bir ayrıntı yok denilebilir, Fransa'da Strabourg şehrinde "Eski Fransa" adlı semtte, tahta evlerinden sokaklarına döşeli taşlarına, Ortaçağ'ı yaşatır. Belçika'da Kuzeyin Venedik'i denilen Bruges, ressam önüne, eski şehrin görüntü ve karakterini serer. Avrupalıların bir zamanlar "Sanat Şehri" olarak sınıflandırdıkları İstanbul ise, eski niteliğini çoktan kaybetmiş görünüyor. Sanat şehri yalnızca anıtlarının eskiliği, değeriyle değil, tarihsel ve doğal görünümleriyle yaşayan şehirdir.

Oysa 19. Yüzyıl ortalarından bu yana İstanbul, kötü Batı akımlarının şehircilik, mimari ve süslemecilik bakımından yavaş yavaş kemirdiği bir deneme tahtası oldu. Klasik Türk sanatı elemanları içine karışarak Türk Rokokosu ile başlayan kemirme yeni yapılarla 
başlamıştı. Yaldızlarla, çeşitli renklerle süslü sivil yapılar, özel ev ve konaklar birer birer yıkılırken yerlerine italyan ustalarının melez üslupları ortaya çıkıyordu. Ama yine de 19. Yüzyılda Lamartine, Théophile Gauiter, Edmundo de Amicis gibi yazarlar eski Türk yapı sanatının son kalıntılarını görerek hayranlıklarını yazılarında belirtiyorlardı.

Eski İstanbul ressam için, eşsiz bir görüntü, motif kaynağıydı. Dünyada hiçbir şehir iki denizi, bir boğazı, karşılıkıı iki kıyıyı, düzlüklerle yamaçları bir araya getiremezdi... Eski İstanbul hem uzaktan, onu çevreleyen tepelerden, hem yakından meydanları ve sokakları ile güzel ve çekici bir şehirdi. Plansızdı, pisti ama hele bir Avrupalı için yepyeni bir görüntü topluluğu olan "pitoresk" karakteri sanatçıya tükenmez bir tema ve konu repertuarı sunardı."

Kentler tarihsel süreçte içinde yaşayan insanların, toplumların kültürel, sanatsal ve tarihsel özelliklerinin birikimi ile gelişir ve değişirler. Gelişmiş ülkelerde şehirlerin sahip olduğu tarihsel, sanatsal ve kültürel değerler mümkün olduğunca korunmaya çalışılmaktadır. Ancak ne kadar korunmaya çalışılırsa çalışılsın kentler zamana karşı yenik düşebilmektedir. Bu bağlamda, kentlerin geçmişten günümüze geçirdiği gelişim ve değişimleri belgelemek önem taşımakta olup; görsel belgeleme çalışmaları ön plana çıkmaktadır. Hiç kuşkusuz günümüzde fotoğraf, video gibi görsel belgeleme teknikleri kullanılmakla beraber fotoğraf makinesinin icat edilmediği dönemlere ilişkin resim sanatı çalışmaları kentsel bellek çalışmalarının yürütülmesinde yardımcı olmaktadır.

$\mathrm{Bu}$ resimler görsel bellek için sanatsal değerin yanı sıra belge niteliği taşımaktadır. Bu resimler dönemlerindeki bir olaya şahitlik etmeleri, toplumsal olayları vurguladıkları, bir değişim ve ilişkiden bahsettikleri için kentsel bellek açısından önemlidirler.

Ancak yapılan çalışma da İstanbul resimleri üzerinden incelemelerde görülmüştür ki; şehirleri ve içindeki yaşamları belgeleyen resimler, eskizler, çizimler ya da yazılı kaynaklardan doğrudan doğadan ve doğadan yorumlanarak olmak üzere üç şekilde yapılmaktadır. İstanbul'u resimlerinde konu alan Batılı ressamlar hayali, gerçekçi ya da yorumlayarak İstanbul'u belgelerken, Türk ressamlar daha çok doğa referanslı çalışarak belgelemişlerdir. Günümüze kadar ulaşmış birbirinden farklı tekniklerle yapılmış resimlerin, belge niteliği taşımasının haricinde, batılı ve Türk ressamların ürettikleri tarihi değeri olan bu sanat eserleri aynı zamanda yaşanılan o dönemin de ruhunun günümüze yansımasıdır. Dolayısıyla İstanbul'u konu alan resimlerin tek başına kentsel belleğin oluşumunu sağlayan görsel belgeler olarak kullanılması yeterli olmamaktadır. Fotoğraflar, tarihi belgeler, sanatsal ve mimari belgeler ile desteklenmeleri gerekir.

Her ne olursa olsun İstanbul geçmişten günümüze tarihsel ve panoramik olarak halen daha cazibesini korumaktadır.

\section{KAYNAKLAR}

Berberoğlu, N., İstanbul'un 100 Camisi: İstanbul Büyükşehir Belediyesi Kültür A.Ş. Yayınları, İstanbul 2013

Berk, N., Yabancı ve Türk Resminde İstanbul, Türkiye Turing ve Otomobil Kurumu, İstanbul 1977

Boppe, A., XVIII.Yüzyıl Boğaziçi Ressamları, Çeviren Nevin Yücel-Celbiş, Pera Turizm ve Ticaret A.Ş., İstanbul 1998 
Mimarlık ve Yaşam Dergisi Cilt: 2, No: 1, 2017 (121-151)

Deniz DEMIRARSLAN, Begüm SAVCIN

Çötelioğlu, A., İstanbul'un 100 Ressamı, İstanbul'un Yüzleri 1, İstanbul Belediyesi Kültür A.Ş Yayınları, İstanbul 2013

Demirarslan, D, "19. Yüzyıl Türk Sivil Mimarisinde Duvar Resmi Estetiği ve İstanbul Teması", Mimarlık ve Yaşam Dergisi, 1(1): 105-125, Kocaeli 2016

Demirarslan, D, "Pedestrian Bridges and Passages in Terms of Space Design", Proceedings of INTCESS 2017 4th International Conference on Education and Social Sciences 6-8 February 2017- Istanbul, Turkey, s. 931-937.

Demirsar Arlı, B, Oryantalizmden Çağdaş Türk Resmine,Toprak Bank Yayınları,İstanbul 2000

Erden, O, Türk Resim Sanatında Bilinmesi Gerekenler, Tempo İstanbul 2012

Gençoğlu, M., "Batı Bili ve Teknolojisinin Osmanlı Bahriyesine Aktarımı", TAD, C. 34/ S. 58, s.603-628. 2015

Grelot, J., Relation nouvelle d'un voyage de Constantinople : enrichie de plans levez par l'auteur sur les lieux, \& des figures de tout ce qu'il y a de plus remarquable dans cette ville, Orthodox Eastern Church. Publisher A Paris : En la boutique de Pierre Rocolet : Chez la veuve de Damien Foucault, https://archive.org/details/gri_relationnouv00grel. 1680

Gürçağlar, A., "Osmanlı Sarayının Son Ressamı Fausto Zauro", Antik Dekor dergisi, Sayı 60. 2000

Kıbrıs, B. , Kesişen Dünyalar: Elçiler ve Ressamlar, Pera Müzesi Yayını 72, İstanbul 2014

Kıbrıs, B., Ögel, Z., Konstantiniyye'den İstanbul'a. XIX. Yüzyıl Ortalarından XX. Yüzyıla Boğaziçi'nin Rumeli Yakası Fotoğrafları, Pera Müzesi Yayınları, İstanbul 2006

Makzume, E., Kocabaşoğlu, E, “Jean Baptiste Vanmour (1671-1737) Kral'ın Doğu'daki Ressamı”, Toplumsal Tarih Sayı 122: 122-124, 2004

Makzume, E, "Felix Ziem (1821-1911) İstanbul ve Venedik Aşığı Ressam, Toplumsal Tarih Sayı 121: 58-61, 2004

Sav, M. , Kuşüzümü, K.H., " Restorasyon Çalışmaları Çerçevesinde Mihrimah Sultan Camii”, Vakıf Restorasyon Yıllığı, S.1,Vakıflar İstanbul 1.Bölge Müdürlüğü Yayını, s.43-53, İstanbul 2010

Şafak, N., 2013, "İstanbul Yeni Cami (Yeni Valide) Külliyesi ve 19. Yüzyılda Geçirdiği Değişimler", Vakıf Medeniyeti ve Şehir Sempozyumu, Vakıflar Genel Müdürlüğü Yayınları,.s 87-94, Ankara 2013

Özcan, A, II.Mahmud Reformları Hakkında Bazı Gözlemle, syf.14, 1995. http://egeweb2.ege.edu.tr/tid/dosyalar/X_1995/TIDX-1995-02.pdf

Özcan, N. , "Jules Verne'den Bir Osmanlı Hicvi: İnatçı Keraban”, Abant İzzet Baysal Üniversitesi Eğitim Fakültesi Dergisi, Cilt: 8, Sayı: 2, Yıl: 8, 68- 72, 2008

Ustaoğlu, C. Fırçaların Diliyle İstanbul, İstanbul Büyükşehir Belediyesi Yayınları, İstanbul 2010 
URL-1: Engiz Türksoy, 2006 http://v3.arkitera.com/h9754-kentin-bellegi.html, erişim tarihi: 11.4.2017.12:25:54

URL-2: http://21inciyuzyilicinplanlama.org/wp-content/uploads/2016/08/Perihan-Kiper02.06.2016.pdf, erişim tarihi: 11.4.2017.12:30:12

URL-3: Yüngül, Naci,

http://earsiv.sehir.edu.tr:8080/xmlui/bitstream/handle/11498/2873/001580151010.pdf?seq uence=3, erişim tarihi: 11.4.2017.12:35:27

URL-4: https://www.rijksmuseum.nl/en/collection/SK-A-4084, erişim tarihi:

11.4.2017.12:40:43

URL-4a: http://www.kanalistanbul.com.tr/tophaneden-cihangire-2-2/:11.4.2017.12:45:30

URL-5: http://eski.istanbulium.net/post/104664984260/atmeydan\%C4\%B1-ve-sultanahmet-camii-ali-r\%C4\%B1za-pa\%C5\%9Fa, erişim tarihi: 11.4.2017.12:47:53

URL5a: http://listelist.com/sultanahmet-meydani/, erişim tarihi: 11.4.2017 .12:48:09

URL-6: http://www.ibb.gov.tr/sites/ks/tr-TR/1-Gezi-Ulasim/tarihi-kopruler/Pages/galata-

koprusu.aspx , erişim tarihi: 10.03.2017.11:28:21

URL-7: http://www.leblebitozu.com/osmanli-istanbulunun-resmini-yapan-19-yabanci-

ressam/ erişim tarihi: 10.03.2017.11:38:35

URL-8: http://www.salom.com.tr/haber-101337-

gocebe_siniflandirilamaz_ve_ayriksi_bir_sanatci_fellx_zlem.html, erişim tarihi:

10.03.2017.11:48:52

URL-9: http://www.galeriearyjan.com/en/felix-ziem-exhibition.htm, erişim tarihi:

11.4.2017.12:29:38

URL-9a: https://gezilmesigerekenyerler.com/istanbul/yeni-camii-nerede-nasil-gidilir-tarihihakkinda-bilgi.html, erişim tarihi: 11.4.2017.12:29:21

URL-10: http://ww2.oilpaintingdecor.com/?folio=7POJ4E717, erişim tarihi:

11.4.2017.12:29:54

URL-11: https://tr.pinterest.com/pin/489555421970193104/, erişim tarihi:

11.4.2017.12:30:22

URL-11a: http://www.beykoz.bel.tr/beykoz/detay/kucuksu-mihrisah-sultan-cesmesi, erişim tarihi: 11.4.2017. 12:30:44

URL-12: https://onokart.wordpress.com/category/orientalizm/page/16/, erişim tarihi:

11.4.2017.12:30:54

URL-13: http://www.istanbulsanatevi.com/sanatcilar/soyadi-c/corrodi-hermann-david-

salomon/hermann-david-salomon-corrodi-1844-1905/, erişim tarihi: 11.04.2017.12:31:14

URL-14: http://www.artnet.com/artists/hermann-david-salomon-corrodi/the-bridge-of-

galata-with-the-yeni-valide-djami-O830kmdjhEJgojypAkGrzQ2, erişim tarihi:

11.4.2017.12:31:34

URI-15: http://www.egitimkutuphanesi.com/galata-koprusu-ii-abdulhamit-tarafindanistanbul39da-halic-uzerine-yaptirilmis-olan-karakoyle-eminonu39nu-birlestiren-koprutarihcesi-2, erişim tarihi: 11.4.2017.12:31:54

URL- 16: http://www.urgupesob.com/index.php/osmanlida-esnaf, erişim tarihi:

11.4.2017.12:32:03

URL-17: https://tr.pinterest.com/pin/389631805243092843/, erişim tarihi: 11.4.2017

URL-18:

http://earsiv.sehir.edu.tr:8080/xmlui/bitstream/handle/11498/14546/001502753006.pdf?se quence=1\&isAllowed=y, erişim tarihi: 11.4.2017.12:37:21

URL-19: http://www.leblebitozu.com/osmanli-istanbulunun-resmini-yapan-19-yabanciressam/, erişim tarihi: 11.4.2017.12:37:36

URL-20: http://www.hayalleme.com/3-galata-koprusu/, erişim tarihi: 22.03.2017.10:33:02 URL-21:http://www.panoramio.com/photo/51795600, sahibi Sevket Sinan Soysal, erişim tarihi: 23.03.2017.10:33:16

URL-22: https://www.artamonline.com/264-muzayede-degerli-tablolar-ve-antikalar/7196francois-prieur-bardin-1879-1939-karakoy-den-eminonu-ne-bakis, erişim tarihi:

23.03.2017.10:33:29 
Mimarlık ve Yaşam Dergisi Cilt: 2, No: 1, 2017 (121-151)

Deniz DEMIRARSLAN, Begüm SAVCIN

URL-23: http://www.i-takvim.com/takvimler/hicri_takvim_cevir.php, erişim tarihi: 29.03.2017.15:33:43

URL-24: https://tr.wikipedia.org/wiki/Jules_Verne, erişim tarihi: 29.03.2017.15:33:57

URL-25: https://www.pinterest.se/pin/561683384756933690/, erişim tarihi:

23.03.2017.10:34:11

URL-26: https://tr.pinterest.com/pin/488077678338555714/, erişim tarihi:

29.03.2017.15:34:25

URL-26a: https://illbefamous.wordpress.com/history-of-the-camera, erişim tarihi:

29.03.2017.15:34:36

URL-27: https://illbefamous.wordpress.com/history-of-the-camera/. erişim tarihi:

24.03.2017.16:34:47

URL-28: http://tweedlandthegentlemansclub.blogspot.com.tr/2015/08/the-pith-helmetvideo-adventures-in.html, erişim tarihi: 30.03.2017 .14:35:02

URL-29: http://canvastar.com/francois-prieur-bardin-uskudar-dan, erişim tarihi:

30.03.2017.14:35:13

URL-30: https://tr.wikipedia.org/wiki/Osman_Hamdi_Bey. erişim tarihi: 14.12.2016.

12:35:30

URL-31: http://turkresmi.com/klasorler/guzelsanatlarbirligi/ erişim tarihi: 14.12 .2016

12:35:36

URL-32: http://www.emo.org.tr/ekler/94a988102edcd4b_ek.pdf, erişim tarihi: 14.12.2016. 12:35:57

URL-33: https://tr.wikipedia.org/wiki/Ahmet_Ziya_Akbulut, erişim tarihi:

14.12.2016.12:36:05

URL-34: http://www.degisti.com/index.php/archives/7261/uskudar_meydan_cesmesi, erişim tarihi: $30.03 .2017 .14: 45: 15$

URL-35: http://www.milliyet.com.tr/fotogaleri/35586-yasam-iste-turk-ressamlarin-imzasinitasiyan-en-degerli-10-tablo/7, erişim tarihi: 30.03.2017.12:50:47

URL-36: http://www.antikalar.com/hikmet-onat/, erişim tarihi: 30.03.2017.12:57:06

URL-37: http://www.antikalar.com/hikmet-onat/, erişim tarihi: 30.03.2017.12:58:23

URL-38: http://www.oguztopoglu.com/2013/09/nazl-ecevitin-salacak-ve-kz-

kulesi.html?spref=pi, erişim tarihi: 30.03.2017 13:37:35 